\title{
Parageobacillus thermantarcticus, an Antarctic Cell Factory: From Crop Residue Valorization by Green Chemistry to Astrobiology Studies
}

\author{
Ilaria Finore ${ }^{1}$, , Licia Lama ${ }^{1}$, Paola Di Donato ${ }^{1,2}$, Ida Romano ${ }^{1}$, Annabella Tramice ${ }^{1}$, \\ Luigi Leone ${ }^{1}$, Barbara Nicolaus ${ }^{1}$ and Annarita Poli ${ }^{1, *}$ \\ 1 Institute of Biomolecular Chemistry, Consiglio Nazionale delle Ricerche, Via Campi Flegrei 34, \\ 80078 Pozzuoli, Italy \\ 2 Department of Science and Technology, University of Naples Parthenope, Centro Direzionale, \\ Isola C4, 80143 Naples, Italy \\ * Correspondence: apoli@icb.cnr.it
}

Received: 13 May 2019; Accepted: 4 August 2019; Published: 7 August 2019

\begin{abstract}
Knowledge of Antarctic habitat biodiversity, both marine and terrestrial, has increased considerably in recent years, causing considerable development in the studies of life science related to Antarctica. In the Austral summer 1986-1987, a new thermophilic bacterium, Parageobacillus thermantarcticus strain M1 was isolated from geothermal soil of the crater of Mount Melbourne $\left(74^{\circ} 22^{\prime} \mathrm{S}, 164^{\circ} 40^{\prime} \mathrm{E}\right)$ during the Italian Antarctic Expedition. In addition to the biotechnological potential due to the production of exopolysaccharides and thermostable enzymes, successful studies have demonstrated its use in the green chemistry for the transformation and valorization of residual biomass and its employment as a suitable microbial model for astrobiology studies. The recent acquisition of its genome sequence opens up new opportunities for the use of this versatile bacterium in still unexplored biotechnology sectors.
\end{abstract}

Keywords: Parageobacillus thermantarcticus; mount melbourne Antarctica; xylanase; beta-xylosidase; xylose/glucose isomerase; protease; exopolysaccharide; draft genoma; astrobiology; xylooligosaccharides

\section{Introduction}

The knowledge of thermophiles biodiversity could be very useful for the discovery of new molecules and/or more thermostable biocatalysts with thermophilic and thermostability properties superior to those currently known and in use [1,2]. Recent exploitations have clearly shown that thermophilic microorganisms are industrial providers of novel catalysts, and in some cases, these enzymes have been cloned and expressed in suitable mesophilic hosts $[1,3]$.

The biggest part of thermophiles studied belongs to the genus Geobacillus, and several strains have been found in thermophilic and mesophilic environments [1,4]. The development of extremophiles from geothermal areas, as a resource for novel thermostable enzymes, has received attention even in Antarctica, where the presence of thermophiles has been indicated by the discovery of several geothermal areas [5]. Thermophilic enzymes (also called thermozymes) work and remain stable at high temperatures, and they are to be preferred to the mesophilic counterpart for their biotechnological potential [6].

In view of this, a thermophilic bacterium, Parageobacillus thermantarcticus, (DSM 9572 ${ }^{\mathrm{T}}$ ) strain M1 [7,8], isolated from geothermal soil of Mount Melbourne $\left(74^{\circ} 22^{\prime} \mathrm{S}, 164^{\circ} 40^{\prime} \mathrm{E}\right.$ ) in Antarctica (Italian Antarctica Expedition during the Austral summer 1986-1987), was characterized for the production of thermostable enzymatic activities such as an extracellular xylanase, a beta-xylosidase, an intracellular xylose/glucose isomerase, and a protease. 
The interesting enzymatic pathways present in P. thermantarcticus make this Antarctic thermophile of great potential in biotechnological applications, not only for industrial biocatalysis but also for bioprocessing aims. In fact, the optimization of enzymatic procedures for the conversion of waste lignocellulosic materials in high added value molecules using the xylanolytic enzymatic set of $P$. thermantarcticus produced extremely interesting results and was recently reported $[9,10]$. These enzymes, which were involved in the enzymatic digestions of hemicellulolitic fraction obtained from rhizomes of Arundo donax and the waste stems and leaves biomasses of Cynara cardunculus, have been used for the bioconversion of agroresidues into xylo-oligomers and fermentable sugars.

Moreover, it was demonstrated that $P$. thermantarcticus produces two exopolysaccharides (called EPS 1 and EPS 2) that are responsible for typical mucous colonies. These EPSs were produced using mannose as a sole carbon and energy source with a yield of $400 \mathrm{mg} / \mathrm{L}$. Nuclear magnetic resonance spectra established that EPS 1 was a xantan polymer, while EPS 2 was a mannan polysaccharide [11].

$P$. thermantarcticus has also been used as a biological model for astrobiology, i.e., the multidisciplinary approach to the study of origin and evolution of life on Earth and in the Universe. It has been demonstrated that either the viable cells or the spores of $P$. thermantarcticus to space simulation are interesting for the issue of the origin of life [12-14]. Indeed, the finding of bacterial species fit to survive in space parameters open new scenarios for the so-called panspermia theory. According to this theory, life on Earth could have originated from bacterial species from other places transported by solar pressure. The identification of bacteria like $P$. thermantarcticus that potentially could survive to the space transport is one main key point to support this theory.

Recently, thanks to participation to "The Genomic Encyclopedia of Bacteria and Archaea (GEBA) III Project", a project of the Community Science Program (CSP) of the DOE Joint Genomes Institute, the draft genomic sequence of $P$. thermantarcticus using the Illumina technology has been obtained. With the available genome sequence, the biotechnology potential and the use of $P$. thermantarcticus will increase. For example, like a factory, $P$. thermantarcticus could convert unexplored feedstocks into useful products such as biobased chemicals, from renewable resources, for biofuels production, bioplastic materials development, etc. The increase of genetic tools is a requirement for high-throughput engineering. There is the opportunity to explore and exploit the physiology of a really interesting bacterium like $P$. thermantarcticus: This will necessarily involve an integrated approach of various disciplines (Figure 1) [15].

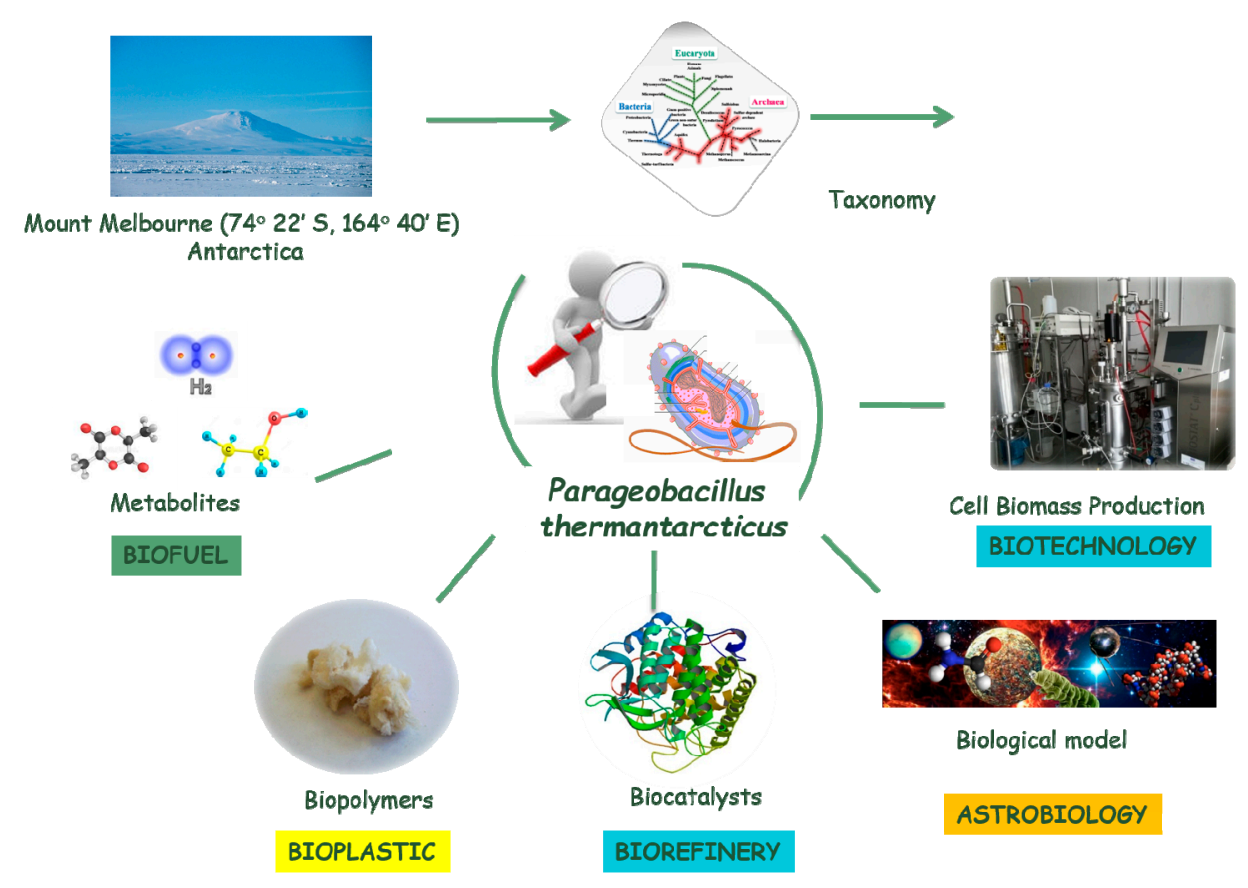

Figure 1. Parageobacillus thermantarcticus: a microbial cell factory. 


\section{Phylogenomic Re-Assessment of Bacillus thermoantarcticus to Parageobacillus thermantarcticus}

It was 1996 when Nicolaus et al. [8] described the isolation and the taxonomic description of a new Antarctic thermophilic species of Bacillus strain M1, isolated from the geothermal soil of Mount Melbourne, for which the name Bacillus thermoantarcticus was indicated. The name thermoantarcticus was subsequently corrected in thermantarcticus (therm.ant.arc'ti.cus. Gr. n. thermệ heat; L. masc. adj. antarcticus southern, belonging to Antarctica; N.L. masc. adj. thermantarcticus, a thermophile from Antarctica) in the Validation List N. 84 published in IJSEM [16]. Nicolaus et al. [8] described strain M1 as able to utilize some sugars such as glucose, trehalose, and xylose as sole carbon sources and overall able to synthesize an exopolysaccharide and some very interesting enzymes: an exocellular xylanase, exo-and endocellular alpha-glucosidase(s) and an intracellular alcohol dehydrogenase. Already at the time of its first description, the M1 strain showed remarkable biotechnological potential thanks to its enzymatic pattern and biopolymer synthesis. The $16 \mathrm{~S}$ rRNA gene sequence analysis placed Bacillus thermantarcticus as a peripheral member of the thermophilic Bacillus rRNA group $5[7,17]$. Bacillus rRNA group 5 comprised thermophilic bacilli with $16 \mathrm{~S}$ rRNA gene sequences similarity ranging between $98 \pm 5 \%$ and $99 \pm 2 \%$ and comprised B. thermoglucosidiasius, B. stearothermophilus, B. kaustophilus, B. thermocatenulatus, B. thermoleovorans, B. thermodenitrificans, and B. thermantarcticus, some isolates not yet validly published and Saccharococcus thermophiles $[18,19]$. A few years later, in 2002, Nicolaus et al. [7] reported that "although the genus Bacillus is the largest and the best-known member of the family Bacillaceae, its taxonomy is very confusing, and new species often have been described on the basis of only a few physiological or ecological features", underlining the necessity of applying a polyphasic approach, including phenotypic, chemical, and genotypic characterization, in order to define a new taxonomic position of endospore forming thermophiles.

Nazina et al. [20] isolated five hydrocarbon-oxidizing strains from formation waters of oilfields in China, Russia, and Kazakhstan and compared their 16S rRNA gene sequences with those available for other members of the Bacillaceae. Strains were further studied for their physiological and biochemical aspects, including analysis of cell membrane fatty acid composition and DNA-DNA hybridization analysis with the most closely related Bacillus species. Nazina et al. [20], based on their studies, proposed creating a new genus, Geobacillus gen. nov., including two new species denominated as Geobacillus subterraneus sp. nov. and Geobacillus uzenensis sp. nov., and proposed the shift of the validly described species of group 5, B. kaustophilus, B. thermoglucosidasius, B. stearothermophilus, B. thermoleovorans, B. thermocatenulatus, and B. thermodenitrificans, to this new genus, with Geobacillus stearothermophilus (formerly Bacillus stearothermophilus DSM $22^{\mathrm{T}}$ ) as the type species of the genus. Moreover, the authors suggested an in-depth study and analysis to establish the taxonomic position of the not yet validated species as 'B. caldotenax', 'B. caldovelox', 'B. caldolyticus', 'B. caldoxylolyticus', 'B. thermoantarcticus', and Saccharococcus thermophilus, present in group 5.

Subsequently, Bacillus pallidus [21], Saccharococcus caldoxylosilyticus [22], and Bacillus vulcani [23] were transferred to Geobacillus [24-26], and then Miñana-Galbis et al. [27] suggested the further transfer of Geobacillus pallidus to the new genus Aeribacillus. Moreover, the following new species Geobacillus toebii [28], Geobacillus gargensis [26], Geobacillus debilis [25], Geobacillus lituanicus [29], Geobacillus tepidamans [30], and Geobacillus jurassicus [31] were proposed. Coorevitis et al. [32] performed a modern polyphasic study to clarify the taxonomy of some members of the Geobacillus genus, such as Bacillus thermantarcticus, also including G. stearothermophilus-the type of species of the genus Geobacillus — whose taxonomic description was mainly provided by Claus and Berkeley [33]. Even Zeigler in 2005 [34] had suggested that B. thermantarcticus should be transferred to the genus Geobacillus, relying on recN and $16 \mathrm{~S}$ rRNA gene sequences. Coorevitis et al. [32] demonstrated that B. thermantarcticus, from a phenotypic and phylogenetic point of view, was distant from the type strain of G. thermoglucosidasius (now G. thermoglucosidans), suggesting the transfer to the genus Geobacillus as the separate species Geobacillus thermantarcticus comb. nov.

Aliyu et al. [35], in subsequent experiments, using the phylogenomic metrics AAI (average aminoacid identity), ANI (average nucleotide identity), and dDDH (digital DNA-DNA hybridization) 
applied to 63 genome sequences of Geobacillus strains, came to the conclusion that the genus Geobacillus comprised sixteen distinct genomospecies and, among these, also different and potential new species. Moreover, the authors stated that the genus Geobacillus clusters into two monophyletic clades with different nucleotide base compositions: the clade I, containing a $G+C$ content range of $48.8-53.1 \%$, and the clade II, in which the G $+C$ content range is $42.1-44.4 \%$. The authors, therefore, suggested that all Geobacillus species that fall in the clade II can be clustered into a new genus and created a new genus, Parageobacillus (Pa.ra.ge.o.ba.cil'lus. Gr. prep. Para, beside or alongside of; n. Gê the Earth; L. dim. n. bacillus small rod; M.L. masc. n. Parageobacillus, a genus nearest to Geobacillus). The Parageobacillus genus included five "genomospecies", P. toebii, P. caldoxylosilyticus, P. thermantarcticus, P. thermoglucosidasius, and Parageobacillus genomospecies 1 (strain NUB3621). The current position of $P$. thermantarcticus is shown in Figure 2, in which the Antarctic bacterium was analyzed using the EzTaxon-e server. The phylogenetic tree was reconstructed using the software MEGA version 5 after multiple alignments of the data by CLUSTAL_X. Distances (distance options according to Kimura's two-parameter model) and clustering were based on the neighbor-joining method [32].

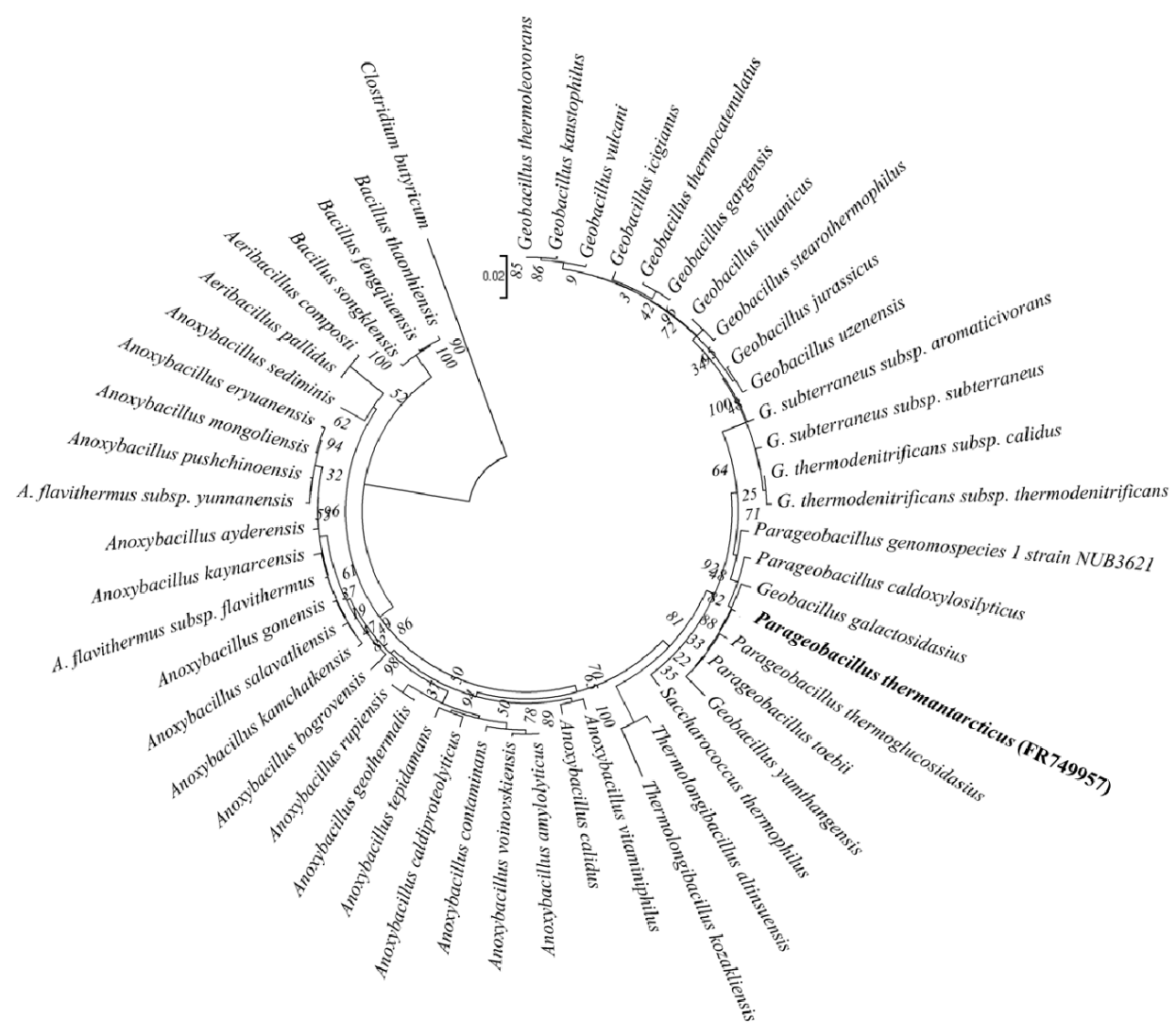

Figure 2. Neighbor-joining phylogenetic tree, constructed using the $16 \mathrm{~S}$ rRNA gene sequences of type strains, showing the position of $P$. thermantarcticus and related taxa. Clostridium butyricum was used as an outgroup.

\section{Main Enzymes in P. thermantarcticus}

\subsection{Xylanase and $\beta$-Xylosidase}

$\beta-1,4-X y l a n$ is the major hemicellulose component of lignocellulose biomass [36]. For complete hydrolysis and assimilation of xylans, various enzymes are necessary, among them $\beta-1,4$-xylanase (1,4- $\beta$-D-xylan xylanohydrolase; E.C 3.2.1.8,) and $\beta$-xylosidase (1,4- $\beta$-D-xylan xylohydrolase; EC 3.2.1.37) [37]. Many thermostable xylanases and beta-xylosidases come from thermophilic and hyperthermophilic bacteria, including species of the genera Thermoanaerobacter, Thermotoga, 
Thermoanaerobacterium, and Geobacillus [38-42]. The pulp and paper industry are among the major potential applications in which xylanases are involved; in fact, the hydrolysis of xylan facilitates the release of lignin from paper pulp and reduces the use of chlorine as a bleaching agent $[43,44]$. Xylanases, for their ability to catalyze the bioconversion of lignocellulosic material and agrowastes into high-value products such as biofuels, furfural, xylitol, and artificial low-calorie sweeteners, are commercially important [45]. Xylanolytic enzymes are known to improve the digestibility of animal feed because they break down arabinoxylans and reduce the viscosity of the raw material [46].

The thermostable xylanases obtained from thermophilic microorganisms are more advantageous in comparison to mesophilic counterparts for potential industrial application and bioprocesses. In general, the xylanase showing activity in extreme conditions such as extreme heat and cold, acidity or alkalinity, and high salinity are interesting to be investigated for many purposes. Most likely, the genus Geobacillus is the genus that contains many species capable of producing thermostable xylanase [47].

Degradation of hemicellulose by Geobacillus spp. is due to the presence of the HUS locus that is the locus responsible for hemicellulose utilization and presents in most strains belonging to this genus. In fact, the xynA gene, which encodes an extracellular endo-xylanase and is the key enzyme to initiate hemicellulose degradation, is present in this locus [48]. Several Geobacillus endo-xylanases have been characterized for their optimum temperature, optimum $\mathrm{pH}$, and generation of degradation products. In particular, two species have been reported to be highly thermostable enzyme producers, Geobacillus $s p$. WSUCEF1 isolated from soil and Geobacillus sp. DUSELR 13 isolated from the deep gold mines of South Dakota $[49,50]$. Xylanase from Geobacillus sp. WSUCEF1 showed a half-life of 18 days and 12 days at $60^{\circ} \mathrm{C}$ and $70{ }^{\circ} \mathrm{C}$, respectively, while Geobacillus sp. DUSELR 13 produced $31 \mathrm{U} / \mathrm{mL}$ after optimization and exhibited a half-life of 13 days at $60^{\circ} \mathrm{C}$ and $70{ }^{\circ} \mathrm{C}[49,50]$.

Another example is the thermo-alkali-stable and cellulose-free endo-beta-1,4-xylanase from $G$. thermodenitrificans A333 [51].

This enzyme showed the highest activity at $70{ }^{\circ} \mathrm{C}$ and $\mathrm{pH}$ 7.0-7.5; moreover, a significant thermal stability was shown by residual activities of $90 \%$ and $88 \%$, after $24 \mathrm{~h}$ of incubation at $58{ }^{\circ} \mathrm{C}$ and $60^{\circ} \mathrm{C}$, respectively, along with half-lives of 94.6 and $73 \mathrm{~h}$. In addition, enzyme stability at alkaline $\mathrm{pH}$ values were also demonstrated: The activity remained unaltered for $24 \mathrm{~h}$ at $\mathrm{pH} 8.0$ and 9.0, and by a residual activity of $75 \%$, at $\mathrm{pH} 10.0$ after $24 \mathrm{~h}$. Knowing its high stability in the presence of high temperature and alkali, the enzyme from Geobacillus thermodenitrificans A333 is suitable for the production of xylo-oligosaccharides (XOS), taking into account the higher solubility of xylan in alkaline solutions.

Xylanolytic enzymes from Geobacillus strearothermophilus T-6, in particular, an endo- $\beta$-D-1,4-xylanase, $\beta$-D-xylosidase, $\alpha$-arabinofuranosidase, and $\alpha$-glucuronidase, have been studied [52]. Moreover, thermostable bacterium Geobacillus thermoleovorans IT-08 producing xylanolytic enzymes isolated from the hot springs at Gunung Pancar, Bogor, West Java, and Indonesia were also described [53]. Another interesting strain of Geobacillus thermodenitrificans named TSAA1 was isolated from hot compost samples collected from compost plants in Japan. This strain was found to produce thermostable endoxylanase and beta-xylosidase. The beta-xylosidase was optimally active at $\mathrm{pH} 7.0$ and $60^{\circ} \mathrm{C}$, while the endoxylanase was active over a broad range of $\mathrm{pH}(5.0-10.0)$ and temperatures $\left(30-100^{\circ} \mathrm{C}\right)$ with optima at $\mathrm{pH} 7.5$ and $70{ }^{\circ} \mathrm{C}$. The $\mathrm{T} 1 / 2$ values of the beta-xylosidase and endoxylanase were $180 \mathrm{~min}$ at $70{ }^{\circ} \mathrm{C}$ and $30 \mathrm{~min}$ at $80^{\circ} \mathrm{C}$, respectively [40].

Recently, Sari et al. described the conventional and molecular characterizations of a new xylanase from Geobacillus galactosidasius strain BS61 with an optimum temperature of $60^{\circ} \mathrm{C}$. The enzyme activity was maintained fully after $24 \mathrm{~h}$ and over $50 \%$ after $168 \mathrm{~h}$ at $\mathrm{pH} 4.0-10.0$, while optimum $\mathrm{pH}$ was 7.0. [54].

The Antarctic isolate, $P$. thermantarticus, produced extracellular xylanase (1,4- $\beta$-D-xylan xylanohydrolase; E.C 3.2.1.8) and beta-xylosidase (1,4- $\beta$-D-xylan xylohydrolase; EC 3.2.1.37). Both enzymatic activities were expressed in a late exponential growth phase and can be induced by specific growth conditions. Among the carbon sources tested, the best inducer for both enzymes' expression was xylan, which enhanced xylanase and beta-xylosidase activities 11-and 21-fold, respectively [55]. Comparing the optimal working conditions of $P$. thermantarcticus $\left(80{ }^{\circ} \mathrm{C}\right.$ and $\mathrm{pH} 5.6$ for xylanase 
and $70{ }^{\circ} \mathrm{C}$ and $\mathrm{pH} 6.0$ for beta-xylosidase) with those described for the other Bacillus species here reported, the peculiarity of this bacterium emerges in terms of optimum activity. Moreover, in terms of stability, at $\mathrm{pH} 8.0$, xylanase from $P$. thermantarcticus retained $43 \%$ of activity found at the optimal $\mathrm{pH}$, while beta-xylosidase retained $34 \%$ of the maximum activity at $\mathrm{pH} 4.0$ and 8.0. The xylanase from $P$. thermantarticus at $60^{\circ} \mathrm{C}$ was stable for $24 \mathrm{~h}$, whereas after $24 \mathrm{~h}$ at $70{ }^{\circ} \mathrm{C}$, about half of the initial activity remained [55]. The purified xylanase digested xylan to form mainly xylobiose and xylotriose, while purified beta-xylosidase did not digest xylan. The analysis of hydrolytic products was performed at different temperatures using crude extract as an enzyme source. The behavior of two enzymes, in mixture, with respect to the reaction products, was different with respect to the incubation temperature. In fact, at $70{ }^{\circ} \mathrm{C}$ after $24 \mathrm{~h}$ of incubation, the major product of hydrolysis was xylose. These results showed that xylanase cleaved the substrate to liberate xylo-oligosaccharides, and then the resulting oligosaccharides have been cleaved to form xylose by beta-xylosidase action. At a temperature of $80^{\circ} \mathrm{C}$, after $24 \mathrm{~h}$, the relative amounts of xylobiose and xylotriose increased with respect to xylose, probably due to lower thermostability of beta-xylosidase compared with xylanase.

Considering the Antarctic biodiversity, in literature, there are several examples of fungi able to produce cold-adapted xylanase [56] or examples of Antarctic yeast able to use as cheaper growth media the lignocellulosic bioethanol distillery wastewater, which contains a large amount of xylose, and concurrently able to produce endo- $\beta$-xylanases [57]. As regards the Antarctic bacterial microorganisms possessing xylanase activity, recently, a new haloalkaliphilic, non-endospore-forming actinobacterium, named Nesterenkonia aurantiaca, was isolated from a soil sample, collected at Cape King (Antarctica) [58], and it was found to be able to hydrolyse xylan on an agar plate.

Considering that the large-scale production of endo-xylanases has already been expressed with success in several hosts but with an expression of variable levels ranging from $2 \mathrm{mg} / \mathrm{L}$ to $148 \mathrm{mg} / \mathrm{L}$, the possibility to also express the xylanases from Parageobacillus thermantarcticus in a suitable host could represent the next challenge in the field of its commercial production.

\subsection{Xylose (Glucose) Isomerase}

D-xylose isomerase is an enzyme of industrial interest both for its ability to isomerize D-xylose into xylulose, which can be finally fermented in ethanol by conventional yeasts, and for the conversion of D-glucose into fructose, producing syrup enriched with high fructose corn (HFCS) [59,60].

P. thermantarcticus produced cytoplasmatic D-xylose(glucose) isomerase at the late exponential growth phase. The enzyme is able to transform both xylose and glucose into their isomers, xylulose and fructose, respectively. Production of the enzyme was investigated on growth media containing different carbon sources, and the best enzyme yield was obtained in the media containing xylose, both for xylose isomerase and glucose-isomerase. The growth on xylan caused a 23-fold increase in xylose isomerase expression but did not induce glucose isomerase [61]. The enzyme was a homotetramer with a native molecular mass of $200 \mathrm{kDa}$ and a subunit molecular mass of $47 \mathrm{kDa}$. The enzyme was purified 73-fold, and D-glucose isomerase activity was co-purified exactly with D-xylose isomerase activity. The enzyme had a Km of $33 \mathrm{mM}$ for xylose and also accepted D-glucose as a substrate. Its optimum $\mathrm{pH}$ was around 7.0 , and it had $80 \%$ of its maximum activity at $\mathrm{pH} 6.0$. Arrhenius plots of the enzyme activity of xylose isomerase were linear up to a temperature of $85^{\circ} \mathrm{C}$. D-Xylose(glucose) isomerase from Parageobacillus thermantarcticus was remarkably stable in high temperatures. For its activity and thermal stability, this enzyme required divalent cations. $\mathrm{Mn}^{2+}, \mathrm{Co}^{2+}$ or $\mathrm{Mg}^{2+}$ were of comparable efficiency for xylose isomerase reaction, while $\mathrm{Mg}^{2+}$ was necessary for glucose isomerase reaction. As a result, this enzyme, stable at acidic $\mathrm{pH}$ values, is interesting from a biotechnology point of view that may reduce the possibility of by-product formation and may increase the efficiency of the process [62].

Xylose isomerase has been used to convert xylose to xylulose, allowing S. cerevisiae to metabolize xylulose into ethanol during fermentation. These approaches have included isomerization, followed by fermentation and simultaneous isomerization and fermentation, and it is likely to be put into operation 
once an acid-stable enzyme is discovered. Therefore, xylose (glucose) isomerase from P. thermantarcticus could be an ideal candidate for the production of ethanol [63].

Furthermore, the high stability of the xylose isomerase is further confirmed by the fact that the enzyme could be immobilized with different techniques without serious losses of enzyme activity. Indeed, immobilized cells of $P$. thermantarcticus in sodium alginate, showed the ability to produce xylulose, when was used xylose as substrate, obtaining the same conversion as the free enzyme within $24 \mathrm{~h}$. The same behavior was obtained by using glucose as a substrate [64].

Various thermophilic xylose isomerases were also described [61-68]. The molecular weight of about 200,000 Da for the native D-xylose isomerase from P. thermantarcticus and of 47,000 Da for its subunits indicate that the enzyme was similar to those enzymes synthesized by Thermus aquaticus Thermus thermophilus Thermotoga maritima and Thermotoga neapolitana, [64-67], while the D-xylose isomerase from G. stearothermophilus was described as a monomer with a MW of 127,000 Da [68] (Table 1). P. thermantarcticus enzyme showed an optimum temperature of $90{ }^{\circ} \mathrm{C}$ and a highly thermostability, similar to the isomerase from Thermotoga maritima that has an optimum temperature at $100^{\circ} \mathrm{C}$ (Table 1 ). The optimum $\mathrm{pH}$ for the P. thermantarcticus was 7.0, (Table 1) 6.5-7.5 for the Thermotoga maritima, 7.5-8.0 for the G. stearothermophilus, 6.0 for Streptomyces and 6.8 for the Thermoanaerobacterium [61,69-73]. Kinetic characteristics for xylose or glucose isomerization were similar to xylose isomerases from distantly related bacteria such as the ones from Thermotoga and Thermus (Table 1) [65-68,73]. In addition to G. stearothermophilus, Konak et al. also described the characterization of xylose isomerases from G. thermodenitrificans TH2 having a molecular weight of $49 \mathrm{kDa}$ on SDS-PAGE [74]. Moreover, in the presence of D-glucose as a substrate, the optimum temperature and $\mathrm{pH}$ of the enzyme were found to be 80 degrees $C$ and 7.5, respectively. From this overview, the native xylose isomerases from $P$. thermantarcticus reveals its high thermostability in comparison with the other species reported. The extracellular production of xylose isomerase from Bacillus sp. NCIM 59 and its purification and characterization were reported by Chauthaiwale and Rao [75].

Table 1. Physical-chemical properties of xylose/glucose isomerases from thermophilic microorganisms.

\begin{tabular}{|c|c|c|c|c|}
\hline Microorganisms & $\begin{array}{c}\text { Molecular } \\
\text { Weight (kDa) }\end{array}$ & $\begin{array}{c}\text { Optimum } \\
\text { Temperature }\left({ }^{\circ} \mathrm{C}\right)\end{array}$ & Optimum pH & Thermostability \\
\hline $\begin{array}{l}\text { Parageobacillus } \\
\text { thermantarcticus }\end{array}$ & 200 & 90 & 7.0 & $90{ }^{\circ} \mathrm{C}$ \\
\hline $\begin{array}{c}\text { Geobacillus } \\
\text { stearothermophilus }\end{array}$ & 130 & 80 & $7.5-8.0$ & $75^{\circ} \mathrm{C}$ \\
\hline $\begin{array}{c}\text { Geobacillus } \\
\text { thermodenitrificans TH2 }\end{array}$ & $49 *$ & 80 & 7.5 & $50^{\circ} \mathrm{C} \times 4$ days \\
\hline Bacillus sp. (NCIM 59) & 160 & 85 & 8.0 & $80^{\circ} \mathrm{C}$ \\
\hline Thermotoga maritima & 200 & $105-110$ & $6.5-7.5$ & $100^{\circ} \mathrm{C}$ \\
\hline Thermotoga neapolitana & 200 & 95 & 7.1 & Half life $95^{\circ} \mathrm{C} \times 24^{\prime}$ \\
\hline Thermus thermophilus & 200 & 95 & 7.0 & $85^{\circ} \mathrm{C} \times 8 \mathrm{~h}$ \\
\hline Thermus aquaticus HB8 & 196 & 85 & 7.5 & $70^{\circ} \mathrm{C} \times 1$ month \\
\hline $\begin{array}{l}\text { Thermoanaerobacterium } \\
\text { saccharolyticum B6AR1 }\end{array}$ & 200 & 80 & $7.0-7.5$ & $85^{\circ} \mathrm{C} \times 1 \mathrm{~h}$ \\
\hline $\begin{array}{c}\text { Thermoanaerobacterium } \\
\text { JW/SL-YS } 489\end{array}$ & 200 & 80 & 6.8 & $80^{\circ} \mathrm{C} \times 1 \mathrm{~h}$ \\
\hline $\begin{array}{c}\text { Clostridium } \\
\text { thermosulfurogenes }\end{array}$ & 200 & 80 & $7.0-7.5$ & $85^{\circ} \mathrm{C} \times 1 \mathrm{~h}$ \\
\hline Streptomyces sp. (PLC) & 183 & 80 & 7.0 & $53^{\circ} \mathrm{C} \times 10$ days \\
\hline Streptomyces sp. SK & 185 & 95 & 6.0 & $80^{\circ} \mathrm{C} \times 5 \mathrm{~h}$ \\
\hline
\end{tabular}

${ }^{*}$ In denaturing condition by SDS-PAGE. 


\subsection{Protease(s)}

Proteases constitute one of the most important groups of enzymes produced commercially; indeed, they are widely applied in the preparation of detergents, proteins, in waste treatment, etc. [76].

A number of thermophilic Bacillus spp. has been reported to produce useful enzymes; in fact, this genus represents the best sources of industrial enzymes [77,78]. In the case of Bacillus sp., the most widespread proteases are metalloproteases (i.e., B. stearothermophilus), serine proteases (i.e., B. subtilis, B. pumilus) and cysteine proteases (i.e., B. licheniformis) [79].

Bacillus proteases are predominantly alkaline and have $\mathrm{pH}$ activity values above 7.0. Their molecular weight usually ranges from 27 to $71 \mathrm{kDa}$, with an optimal $\mathrm{pH}$ range between 6 and 10 . The optimal temperatures are between $37^{\circ} \mathrm{C}$ and $60^{\circ} \mathrm{C}$. Moreover, these proteolytic enzymes exhibit remarkable stability over a wide range of $\mathrm{pH}$ values and temperatures [79].

$P$. thermantarcticus produced an extracellular proteolytic enzyme [80]. In accordance with most extracellular proteases secreted by Bacilli, the protease from $P$. thermantarcticus was found in the supernatant free-cells, and its maximum yield was detected after $12 \mathrm{~h}$, at the end of the exponential growth phase [81]. The extracellular protease here described was strongly induced by growth conditions, such as the presence of skim milk in the growth medium. In fact, the highest protease production (ca. 19 times more with respect to the medium $\mathrm{YN}$ ) was reached when the microorganism was grown on medium A containing skim milk $0.1 \%$. With respect to the medium YN Medium B, with and without skim-milk $0.1 \%$, a moderate increase (ca. 2 times) on protease production was observed (Table 2).

Table 2. Effect of different media on extracellular $P$. thermantarcticus protease production.

\begin{tabular}{cccc}
\hline Media & $\begin{array}{c}\text { Cell Growth } \\
\text { (O.D.540 nm) }\end{array}$ & $\begin{array}{c}\text { Protease Total } \\
\text { Units }\end{array}$ & $\begin{array}{c}\text { Protease Production } \\
\text { (U/O.D.540 nm) }\end{array}$ \\
\hline YN & 1.705 & 17.6 & 10.3 \\
YN + milk 0.1\% & 1.915 & 18.4 & 9.6 \\
Medium A & 0.918 & 30.0 & 32.7 \\
Medium A + milk 0.1\% & 1.334 & 253 & 190 \\
Medium B & 1.290 & 28.8 & 22.3 \\
Medium B + milk 0.1\% & 1.660 & 35.2 & 21.2 \\
\hline
\end{tabular}

* After $24 \mathrm{~h}$ of growth at $60^{\circ} \mathrm{C}, \mathrm{pH} 6.5$, the protease activity was assayed with $250 \mu \mathrm{L}$ of extracellular broth in the standard assay conditions. YN (standard medium): yeast extract $0.6 \mathrm{~g} / \mathrm{L} ; \mathrm{NaCl} 0.3 \mathrm{~g} / \mathrm{L}$; Medium A $(\mathrm{g} / \mathrm{L}$ ): yeast extract 1.0, tryptone-soya broth $0.8, \mathrm{CaSO}_{4} \cdot 2 \mathrm{H}_{2} \mathrm{O} 0.36, \mathrm{MgCl}_{2} \cdot 6 \mathrm{H}_{2} \mathrm{O} 1.6$, iron citrate $0.01 \mathrm{M} 4.0 \mathrm{~mL}$, in distilled water, and the $\mathrm{pH}$ of the medium was adjusted to 6.0 with $\mathrm{NaOH}$ or $\mathrm{H}_{2} \mathrm{SO}_{4}$; Medium B: bactopeptone $15 \mathrm{~g}, \mathrm{~K}_{2} \mathrm{HPO}_{4} 2.9 \mathrm{mM}$ and $\mathrm{MgCl}_{2} \cdot 6 \mathrm{H}_{2} \mathrm{O} 5 \mathrm{mM}$ in $1 \mathrm{~L}$ of distilled water.

The molecular mass was about $42 \mathrm{kDa}$. Protease from P. thermantarcticus was almost total inhibited by phenyl methyl sulphonylfluoride (PMSF), which suggested that the enzyme belonged to the serine protease family. The protease showed the highest activity and was stable for $24 \mathrm{~h}$ at $70{ }^{\circ} \mathrm{C}$. The enzyme was active and stable in a broad range of $\mathrm{pH}$ with an optimum at $\mathrm{pH}$ 7.0., and in the presence of $\mathrm{CaCl}_{2}$ showed an increase of the enzymatic activity of about four times. In the presence of various commercial detergents, the protease retained about $50 \%$ activity after $3 \mathrm{~h}$ of incubation in the presence of $\mathrm{CaCl}_{2 .,}$ Purified protease was found to be stable, for one week, in the presence of DMSO, methanol, ethanol, acetonitrile, and isopropanol.

The protease produced by P. thermantarcticus was also resistant to surfactants, as SDS, DBS, and Triton X-100 [80]. The enhancement of activity in the presence of SDS was not examined; this could be attributed either to the susceptibility of the substrate to SDS, making it more sensible to use enzyme hydrolysis, or to the exposure of the active site of the enzyme [81]. In addition, the protease isolated by $P$. thermantarcticus showed stability and compatibility with some commercial detergents in the presence of $\mathrm{CaCl}_{2}$. The purified protease from $P$. thermantarcticus possesses thermophilicity, thermostability, resistance to organic solvent and detergents, with extensive activity in the $\mathrm{pH}$ range, characteristics that make it particularly interesting for applications in the detergent sector [82-84] (Table 3). 
Table 3. Characteristics of some Bacillus and Geobacillus proteases in comparison with P. thermantarcticus protease.

\begin{tabular}{|c|c|c|c|}
\hline Microorganisms & $\begin{array}{c}\text { Molecular Mass } \\
\text { (kDa) }\end{array}$ & $\begin{array}{l}\text { Optimal pH and } \\
\text { Temperature }\end{array}$ & $\begin{array}{c}\mathrm{pH} \text { and Temperature } \\
\text { of the Stability }\end{array}$ \\
\hline B. megaterium RRM2 & 27 & $\mathrm{pH} 10$ and $60^{\circ} \mathrm{C}$ & $\begin{array}{c}\mathrm{pH} 7-11 \text { and } 60^{\circ} \mathrm{C} \text { for } \\
2 \mathrm{~h} \text { of incubation }\end{array}$ \\
\hline B. koreensis BK-P21A & 48 & $\mathrm{pH} 9.0$ and $60^{\circ} \mathrm{C}$ & $\begin{array}{c}\mathrm{pH} 7-10 \text { and } 70{ }^{\circ} \mathrm{C} \text { for } \\
1 \mathrm{~h} \text { of incubation }\end{array}$ \\
\hline B. alveayuensis CAS5 & 33 & $\mathrm{pH} 9.0$ and $50^{\circ} \mathrm{C}$ & $\begin{array}{c}\mathrm{pH} 8-11 \text { and } 80^{\circ} \mathrm{C} \text { for } \\
1 \mathrm{~h} \text { of incubation }\end{array}$ \\
\hline $\begin{array}{l}\text { B. amyloliquefaciens } \\
\text { SYB-001 }\end{array}$ & 36.8 & $\mathrm{pH} 7.0$ and $50^{\circ} \mathrm{C}$ & $\begin{array}{c}\mathrm{pH} 6-10 \text { and } 60^{\circ} \mathrm{C} \text { for } \\
1 \mathrm{~h} \text { of incubation }\end{array}$ \\
\hline B. subtilis GA CAS & 41 & $\mathrm{pH} 9.0$ and $50^{\circ} \mathrm{C}$ & $\begin{array}{l}\mathrm{pH} 9-11 \text { and } 60^{\circ} \mathrm{C} \text { for } \\
24 \mathrm{~h} \text { of incubation }\end{array}$ \\
\hline P. thermantarcticus & 42 & $\mathrm{pH} 7.0$ and $70^{\circ} \mathrm{C}$ & $\begin{array}{c}\mathrm{pH} 7-10 \text { and } 70{ }^{\circ} \mathrm{C} \text { for } \\
24 \mathrm{~h} \text { of incubation }\end{array}$ \\
\hline Geobacillus YMTC 1049 & 59.2 & $\mathrm{pH} 7$ and $85^{\circ} \mathrm{C}$ & $\begin{array}{l}\mathrm{pH} 6.0-9.0 \text { and } 65^{\circ} \mathrm{C} \\
\text { for } 10 \mathrm{~h} \text { of incubation }\end{array}$ \\
\hline Geobacillus toebii LBT 77 & 30 & $\mathrm{pH} 13$ and $95^{\circ} \mathrm{C}$ & $\begin{array}{l}\mathrm{pH} 9.0-13.0 \text { and } 95^{\circ} \mathrm{C} \\
\text { for } 70 \mathrm{~min}\end{array}$ \\
\hline
\end{tabular}

In regard to examples of protease-producing bacteria in the Antarctic continent, Zhou et al. studied the diversity of the cultivable protease-producing bacteria in the sediments of Maxwell Bay, King George Island, Antarctica [85]. The authors found that Pseudoalteromonas and Flavobacteria strains showed relatively high protease production. Moreover, Vazquez et al. (2004) studied proteases from eight Antarctic psychrotolerant Pseudomonas sp. strains. They found that all of them showed an apparent molecular mass of $45 \mathrm{kDa}$, optimal activity at $40{ }^{\circ} \mathrm{C}$, and $\mathrm{pH} 7-9$. In this case, these enzymes showed low thermal stability with a half-life ranging from 20 to $60 \mathrm{~min}$ at $40^{\circ} \mathrm{C}$ and less than $5 \mathrm{~min}$ at $50{ }^{\circ} \mathrm{C}[86]$.

\section{Production of Xylo-Oligosaccharides as High Value-Added Molecules}

$\beta-1,4-x y l a n$ is the second most widespread polymer present in nature, representing one-third of the available renewable biomass $[10,87]$. Using proper chemical, autohydrolytic, or enzymatic procedures, it is possible to produce (XOS), D-xylose and, to a lesser extent, L-arabinose from crop waste residues and forestry biomass [88-90].

The industrial interest for the xylo-oligosaccharides is increasing because of their nutraceutical properties. These molecules can work as selective prebiotics for the gut microflora, reduce the blood glucose and cholesterol, reduce the procarcinogenic enzymes in the gastrointestinal tract, and enhance mineral absorption from the large intestine. Xylobiose has been shown to have a stimulatory effect on the selective growth of human intestinal Bifidobacteria, which are extremely useful for the maintenance of a healthy intestinal microflora. In addition, XOS, which can be used in anti-obesity diets, are noncariogenic and low-calorie [90-95]. These beneficial effects are caused by the chemical structure of the xylo-oligosaccharides, which in turn are affected by the adopted hemicellulose extraction procedures.

In this sense, xylanases and $\beta$-xylosidases enzymes isolated from thermophilic strains of bacteria and fungi can be considered essential from a biotechnological viewpoint, due to their higher thermostability, and other biochemical properties, which are fundamental for industrial applications $[96,97]$. 
The optimization of enzymatic procedures for the conversion of waste lignocellulosic materials in XOS molecules using the xylanolytic enzymatic set from Geobacillus microorganisms produced extremely interesting results and was recently reported [50,51,98].

In particular, $P$. thermantarcticus produced an extracellular xylanase (1,4- $\beta$-D-xylan xylanohydrolase; E.C. 3.2.1.8) and a $\beta$-xylosidase (1,4- $\beta$-D-xylan xylohydrolase; E.C. 3.2.1.37), which were involved in the enzymatic digestions of hemicellulose extract obtained from rhizomes of Arundo donax L. and the waste biomass of Cynara cardunculus stems and leaves $[9,10]$. Among the several biomass crops for lignocellulosic materials, one of the most interesting is giant reed, $A$. donax. The most useful and studied part of $A$. donax L. is represented by shoots (reeds) of interest in bioethanol, biodiesel or biopolymer production [9].

However, at the end of the cropping cycle of a giant reed stand (10-15 years), a huge number of rhizomes is left on the soils, and they have to be eliminated to allow further agricultural utilizations. These rhizomes could represent a source of useful molecules for bioenergy or biochemicals [9,51].

On the other hand, C. cardunculus is another interesting crop due to its ability to produce both biomass from the whole plant, and oil from the seeds previously removed from the plants [10].

For the extraction of the hemicellulosic fraction from both biomasses, a 72-h alkaline treatment was considered to be the most appropriate in comparison with other methods [99]. In particular, starting from hemicellulose biomass from $A$. donax rhizomes, an extracellular suspension of $P$. thermantarcticus, which contained either xylanase and beta-xylosidase activities, was able to produce, at a temperature of $70{ }^{\circ} \mathrm{C}$, a mixture of xylose and XOS up to five- and six-monosaccharide units; the oligosaccharides amount emerged prevailing in the case of higher ratios between the xylan substrate and the enzyme amounts (substrate/biocatalyst ratio, S/B), as reported in Table 4 [9]. However, the efficiency of these digestion procedures was evaluated as a percentage of the equivalent reducing xylose obtained (dinitrosalicyclic colorimetric assay-DNS-) [100]; in any case, it was over $60 \%$.

Marcolongo et al. [51] reported the saccharification by an alkali-thermostable xylanase from Geobacillus thermodenitrificans A333 of hemicellulose fractions from several agroderived biomasses (brewery's spent grains, corn cobs, and A. donax biomass). The polysaccharidic fractions were obtained after alkali treatment; in particular, the digestion of $A$. donax hemicellulose produced an end-product profile made of xylopentaose, xylotriose, xylobiose (with a prevalence of $X 2$ upon long time incubation), and similar to that recovered using $P$. thermantarcticus xylanase [9]. By contrast, the evaluation of the reducing sugars revealed that the percentage of $A$. donax xylan degradation by $G$. thermodenitrificans A333 xylanase, was very low, also reaching $7.17 \%$ after $72 \mathrm{~h}$ of reaction.

Table 4. Degradative action of $P$. thermantarcticus xylanolytic enzymatic set on hemicellulose extracts form waste agroresidues.

\begin{tabular}{lccccc}
\hline $\begin{array}{c}\text { Hemicellulose } \\
\text { Source }\end{array}$ & $\begin{array}{c}\text { Amount of } \\
\text { Hemicellulose } \mathbf{( m g / m L )}\end{array}$ & Biocatalyst & S/B & RS\% & Xylose \% \\
\hline A. donax & 4 & ES-GTM & 13.5 & 73.5 & 26.5 \\
A. donax & 4.4 & ES-GTM & 36.3 & 63.1 & 9.85 \\
C. cardunculus & 4 & ES-GTM & 3.58 & 62 & 44 \\
C. cardunculus & 4 & ES-GTM endo-xyl & 17.5 & 43.7 & 6.8 \\
C. cardunculus & 4 & ES-GTM endo-xyl + & 17.5 & 73.6 & 62.6 \\
\hline
\end{tabular}

$\mathrm{S} / \mathrm{B}=$ amount of used biocatalyst, corresponding to ratio $\mathrm{mg}$ substrate/mg total protein; $\mathrm{RS}=$ reducing sugars yield $\%$ (DNS assay); ES-GTM = extracellular suspension from P. thermantarcticus.; ES-GTM endo-xyl = endoxylanase from P. thermantarcticus; ES-GTM beta-xyl = beta-xylosidase from $P$. thermantarcticus.

Instead, a yield bioconversion of $62 \%$ and $44 \%$, in terms of reducing sugars (production of xylo-oligosaccharides) and xylose releases, respectively (Table 4), was obtained through the simultaneous use of endoxylanase and $\beta$-xylosidase activities of $P$. thermantarcticus at a temperature of $70^{\circ} \mathrm{C}$, starting from the hemicellulosic fraction isolated from C. cardunculus [10]. MS analysis of the 
reaction mixture after $24 \mathrm{~h}$ suggested the presence of xylose, xylotriose, xylotetraose, and also of two disaccharides: the first made of xylose and $O$-methyl glucuronic acid and the second one of xylose and glucuronic acid.

These results were similar to those obtained from the commercial beechwood xylan digestion using the thermostable xylanase from the Geobacillus sp. strain DUSELR13 [50]. In a second bioprocess, the xylanase and $\beta$-xylosidase activities from $P$. thermantarcticus were separated according to (i) a procedure for the xylanase recovery (ES-GTM endo-xyl) based on differences between the thermal stabilities of the two proteins [55], for which the $\beta$-xylosidase activity could be eliminated by heat treatment at $80{ }^{\circ} \mathrm{C}$ for $20 \mathrm{~min}$, and (ii) a further procedure for the beta-xylosidase recovery, which exploited the possibility of many xylanases to be absorbed on xylan polymers [101]. It was possible to obtain a xylan-bound fraction that contained $100 \%$ of the inactive xylanase and an unbound fraction that contained $100 \%$ of the active $\beta$-xylosidase (ES-GTM beta-xyl) from the extracellular enzymatic pool of $P$. thermantarcticus [10].

These enzymatic preparations (ES-GTM endo-xyl, ES-GTM beta-xyl) were then used individually or consecutively in cascade hydrolysis reactions aiming to accumulate xylose or xylo-derivatives selectively into the reaction media, as reported in Table 4 . The polysaccharide bioconversion after the exclusive ES-GTM endo-xyl attack furnished a yield of $43.7 \%$ as a percentage of reducing sugars with only $6.8 \%$ of the xylose content. In addition, the hydrolysis products after $24 \mathrm{~h}$ were essentially composed of xylobiose $(26.5 \%)$, xylotriose $(5.5 \%)$, and oligomers (DP > 3), as indicated by the HPAE-PAD (High Performance Anion-Exchange. Chromatography with Pulsed. Amperometric Detection) analyses, being the composition of reaction products related to the absence of $\beta$-xylosidase activity. Furthermore, in these experimental conditions, two new tetrasaccharides were produced. Their structures were identified, and chemical shifts were totally assigned by NMR spectroscopy; they corresponded to the 2'-O-(4-O-methyl- $\alpha$-D-glucuronosyl) xylotriose (compound 1 , $\alpha$-D-4OMeGlcA-(1-2)- $\beta$-D-Xyl-(1-4)- $\beta$-D-Xyl-(1-4)- $\beta$-D-Xyl)) and the $2^{\prime}-O-\alpha$-D-glucuronosyl xylotriose (compound 2, $\alpha$-D-GlcA-(1-2)- $\beta$-D-Xyl-(1-4)- $\beta$-D-Xyl-(1-4)- $\beta$-D-Xyl), which were produced with yields of $22 \%$ and $13 \%$, respectively (Figure 3 ).

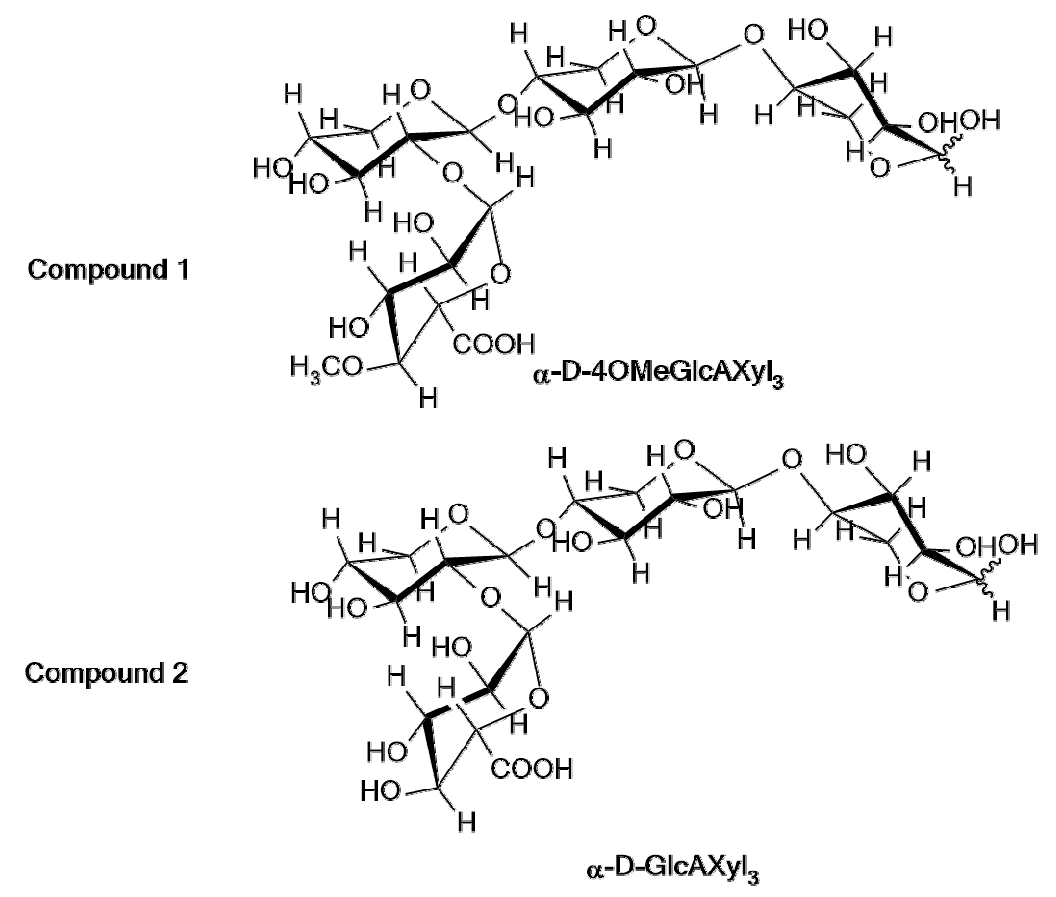

Figure 3. Compounds 1 and 2 produced from hemicellulose extract of C. cardunculus and ES-GTM endo-xyl. 
It is worth emphasizing that a xylotriose substituted by 4-O-methylglucuronic acid located at the non-reducing end, which was structurally similar to compound 2, was later identified by HPAEC analysis of a birchwood xylan depolymerization by the Geobacillus thermodenitrificans T12 endo-xylanase, GtXynA1 [48]. Alternatively, an enzymatic cascade reaction was carried out; in fact, the xylo-oligosaccharides mixture produced by the ES-GTM endo-xyl digestion (line 4, Table 4) was involved in a consecutive hydrolysis step using the isolated $\beta$-xylosidase from $P$. thermantarcticus (ES-GTM beta-xyl) (line 5, Table 4) [10]. In this way, 73\% of reducing sugars were produced with a xylose yield of $62.6 \%$ in the reaction mixture. Exploiting the different optimal temperatures and thermostabilities of each enzyme, in the enzymatic cascade attack, reactions were carried out at a temperature of $70{ }^{\circ} \mathrm{C}$ for the first step (xylanase activity), and at $60{ }^{\circ} \mathrm{C}$ for the second step ( $\beta$-xylosidase activity). In comparison with the digestion procedures involving both hemicellulolytic enzymes (lines 1-4, Table 4), the enzymatic cascade result was more efficient, with an increase of $10 \%$ of reducing sugars and about $20 \%$ of xylose.

The combined use of the xylanase and $\beta$-xylosidase activities from the extremely thermophilic bacterium Geobacillus thermodenitrificans TSAA1 was also previously reported [40]. The endoxylanase was active over a broad range of $\mathrm{pH}(5.0-10.0)$ and temperatures $\left(30-100{ }^{\circ} \mathrm{C}\right)$, with optima at $\mathrm{pH}$ 7.5 and $70{ }^{\circ} \mathrm{C}$, while $\beta$-xylosidase was optimally active at $\mathrm{pH} 7.0$ and $60^{\circ} \mathrm{C}$. In this case, the end products' Thin Layer Chromatography analysis of hydrolysis of xylan from birchwood and xylan containing agroresidues revealed the presence of xylobiose, xylotriose, xylotetraose, xylopentaose, and other higher xylooligosaccharides by the exclusive endoxylanase action. Upon incubation of an enzyme preparation containing both xylanase and $\beta$-xylosidase on xylan containing agroresidues, xylose formation was recorded from the very beginning along with other xylooligosaccharides; on increasing the time of incubation, the xylose band got intensified on TLC.

The synergistic hydrolysis of xylan using a xylanase, $\beta$-xylosidases, and an $\alpha$-L-arabinofuranosidase from Geobacillus thermodenitrificans NG80-2 was described by Huang et al. [102]. The reducing sugars released from birchwood, oat spelt, and beechwood xylan hydrolysis in the presence of xylanase, $\beta$-xylosidase, $\alpha$-L-arabinofuranosidase, or their enzyme combinations suggested that a synergistic effect on each enzymatic activity on hemicellulose degradation was recorded, and the degree of synergy depended on the substrate. However, in any case, yields lower than $60 \%$ in terms of reducing sugars and for processes with a degree of enzymatic synergy of 1.55 were recorded.

Xylooligosaccharides (XOS) and arabinoxylooligosaccharides (AXOS) were produced from the insoluble arabinoxylan fraction of pretreated wheat bran by endoxylanases GsXyn10A from Geobacillus stearothermophilus [98]. The AXOS obtained by xylanase treatment of pretreated wheat bran were analyzed by HPAEC-PAD: The major arabinose-substituted products identified with GsXyn10A were $A^{3} X$, minor amounts of $A^{2} X X$. Their structure was confirmed after enzymatic treatment of AXOS with specific arabinofuranosidases. The prebiotic effect of XOS, AXOS, and mixtures of XOS and AXOS has been reported by Broekaert et al. [103]. In conclusion, the results reported for P. thermantarcticus encouraged the application of these enzymatic separation procedures on the industrial scale. An efficient enzymatic employment in the bioconversion of agroresidues for obtaining both xylo-oligomers and fermentable sugars was here described. Moreover, $P$. thermantarcticus $\beta$-xylosidase, showing a scarce substrate inhibition in agreement with some of the recently discovered $\beta$-xylosidase behavior [104], could represent a useful enzyme for industrial purposes.

\section{Relevance of $P$. thermantarcticus to Astrobiology}

P. thermantarcticus has been used as a biological model for Astrobiology, i.e., the multidisciplinary approach to the study of origin and evolution of life on Earth and in the Universe. The study of extremophiles is particularly relevant for the search of life and for the issue of habitability in the universe-indeed, as also envisaged by the recent European Astrobiology Roadmap [105]. Microbiology experiments, carried out either in space or in laboratories by simulating space conditions, are one main 
tool for the definition of boundaries of life on Earth or on other planetary bodies, i.e., the so-called exoplanets (Mars, Europa, Enceladus, etcetera).

On the basis of these considerations, we exposed cells of $P$. thermantarcticus to the extreme environmental parameters that are typical of space and exoplanets [12,13]. Different laboratory simulations mimicking the extraterrestrial conditions were carried out as schematically reported in Table 5. For all the conditions assayed, the resistance of $P$. thermantarcticus to the space environment's simulation was assessed by measuring the ability to restart cellular growth after the stressing treatments. The simulations performed included: the extreme temperature variations, by storing cells for 3 months at temperatures ranging from $-196{ }^{\circ} \mathrm{C}$ to $80{ }^{\circ} \mathrm{C}$; the absence of water, by storing desiccated cells at $-20^{\circ} \mathrm{C}$ or at room temperature for time intervals up to 1 year; exposition to UV rays at the bactericidal $\lambda$ $254 \mathrm{~nm}$, with doses ranging from $125 \mathrm{~J} / \mathrm{m}^{2}$ up to $1000 \mathrm{~J} / \mathrm{m}^{2}$; finally, the exposure to X-rays, with radiation doses from $100 \mathrm{~Gy}$ up to $1000 \mathrm{~Gy}$. In all cases, cells of $P$. thermantarcticus were able to grow as much as the not stressed cells. As shown in Table 5, only in the case of desiccation and UV-rays exposure, there was a slight delay in the growth's kinetics observed, while for other stressors, no appreciable difference was found with respect to the not stressed samples.

Table 5. Space simulation effects on survival and cellular structures of P. thermantarcticus.

\begin{tabular}{|c|c|c|c|c|}
\hline & $\begin{array}{l}\text { Temperature Variations } \\
\text { (from }-196^{\circ} \mathrm{C} \text { to } 80^{\circ} \mathrm{C} \text { ) }\end{array}$ & $\begin{array}{l}\text { Desiccation } \\
\text { (up to } 1 \text { Year) }\end{array}$ & $\begin{array}{l}\text { UV-Ray Irradiation } \\
\text { (at } \lambda 254 \mathrm{~nm} \text { ) }\end{array}$ & $\begin{array}{l}\text { X-Rays Exposure } \\
\text { (up to } 1 \mathrm{kGy} \text { ) }\end{array}$ \\
\hline Growth's kinetics & n.m. & \multicolumn{2}{|c|}{ Slight delay } & n.m. \\
\hline $\begin{array}{l}\text { Membranes lipids' } \\
\text { fatty acids }\end{array}$ & \multicolumn{4}{|c|}{ Increase of branched fatty acids fraction } \\
\hline $\begin{array}{l}\text { Membranes' } \\
\text { quinones }\end{array}$ & Partial depletion of demet & ted menaquinone & n.m. & $\begin{array}{l}\text { Partial depletion of } \\
\text { demethylated } \\
\text { menaquinone }\end{array}$ \\
\hline Protein pattern & n.m. & n.m. & n.m. & n.m. \\
\hline DNA & n.m. & n.m. & Minor modifications & n.m. \\
\hline
\end{tabular}

n.m. no modification.

Moreover, in order to investigate the biological effectiveness of the space simulation, the analysis of some key cellular structures was performed [13]. As reported in Table 5, membranes, proteins, and DNA were the cellular components that were investigated after exposure to the stressing conditions mimicking the space environment. With regard to membranes, in all the simulations, $P$. thermantarcticus adapted its membranes by increasing its fluidity, as suggested by the increase of the branched fatty acids; on the other hand, a partial decrease in the amount of the demethylated form of menaquinone was observed, except for the UV ray exposure. The effect of ultraviolet radiations was more marked for the DNA, since UV-rays induce the generation of different kinds of photo products [106]; other stressors did not induce a significant modification in the nucleic acid. Finally, the protein component of this bacterium also did not undergo a significant modification to the space simulation.

P. thermantarcticus is a sporulating species, i.e., under unfavorable conditions, like the absence of water or nutrients, excess of pressure, temperature or radiations, its cells undergo conversion into metabolically dormant spores. The spores of different bacterial species, especially those of bacteria from the related Bacillus genus, were also shown to be very resistant for a million years, and for this reason, they have been chosen as a biological model for astrobiology [107]. The investigation of bacterial spores' resistance to ionizing radiations, which represent a major part of the cosmic radiation spectrum, is one of the main issues for the study of habitability. Therefore, further studies were performed using exposure of the spores of $P$. thermantarcticus to irradiation with UV and $\gamma$-rays [14]. In both cases, resistance to irradiation was assessed by measuring $D_{10}$, which represents the radiation dose required to inactivate $90 \%$ of the starting spores' population. As previously described for the viable cells, spores were irradiated with UV at $\lambda 254 \mathrm{~nm}$ with doses from $125 \mathrm{~J} / \mathrm{m}^{2}$ up to $1000 \mathrm{~J} / \mathrm{m}^{2}$ : Irradiation at $125 \mathrm{~J} / \mathrm{m}^{2}$ emerged as the $D_{10}$, thus confirming the hypothesis that UV resistance of viable cells was due to the 
onset of sporulation during irradiation [13]. $\gamma$-ray irradiation, performed using ${ }^{60} \mathrm{Co}$, was carried out in the dose interval from $0 \mathrm{kGy}$ to $15.0 \mathrm{kGy}$. The $\mathrm{D}_{10}$ value was found at about $2.50 \mathrm{kGy}$, a value higher that the majority of spores of other species previously reported (Table 6).

Table 6. D10 values for $\gamma$-ray inactivation of spores from different bacterial species.

\begin{tabular}{ccccccccc}
\hline Species & $\begin{array}{c}\text { Bacillus } \\
\text { pumilus }\end{array}$ & $\begin{array}{c}\text { Bacillus } \\
\text { subtilis }\end{array}$ & $\begin{array}{c}\text { Bacillus } \\
\text { thuringiensis }\end{array}$ & $\begin{array}{c}\text { Salibacillus } \\
\text { marismortui }\end{array}$ & $\begin{array}{c}\text { Bacillus } \\
\text { megaterium }\end{array}$ & $\begin{array}{c}\text { Bacillus } \\
\text { subtilis } \\
\text { luxAB }\end{array}$ & $\begin{array}{c}\text { Parageobacillus } \\
\text { thermantarcticus }\end{array}$ & $\begin{array}{c}\text { Bacillus } \\
\text { cereus }\end{array}$ \\
\hline $\mathrm{D}_{10}$ & $1.26 \mathrm{kGy}$ & $1.5 \mathrm{kGy}$ & $2.0 \mathrm{kGy}$ & $2.0 \mathrm{kGy}$ & $2.50 \mathrm{kGy}$ & $2.50 \mathrm{kGy}$ & $>2.50 \mathrm{kGy}$ & $3.0 \mathrm{kGy}$ \\
\hline
\end{tabular}

The investigation of the effect of $\gamma$-rays on some molecular cells' structures was carried out by means of Raman spectroscopy analysis. Such a technique allowed showing that inactivation of the spores, taking place at doses higher than $2.50 \mathrm{kGy}$, followed two routes. Indeed, some spores underwent the loss of dipicolinic acid (DPA), the main component of the core. The main function of DPA is to protect proteins and DNA from the damages caused by reactive oxygen species (ROS), which in turn are produced by the radiolysis of water induced by radiations. The spores lacking DPA, which is lost after damage in the coat, are therefore not protected from the action of ROS and appeared as dark phase cells at the microscope analysis. On the other hand, the microscopy analysis allowed assessing the persistence of intact spores also at radiation levels higher than $\mathrm{D}_{10}$. The Raman analysis showed that such spores, although still retaining their DPA content, presented a lowering in their DNA and protein integrity, as confirmed by the decrease in the relative Raman signals. In this case, the inactivation was caused by the direct interaction of $\gamma$-rays with the cellular structures and was not mediated by ROS formation [14]. Moreover, the results obtained by subjecting either the viable cells or the spores of $P$. thermantarcticus to space simulation are interesting for the issue of origin of life. Indeed, the finding of bacterial species able to resist space conditions opens new scenarios for the so-called panspermia theory, according to which, early terrestrial life forms could have originated from bacteria transported by solar pressure from other planetary bodies. The identification of bacteria like $P$. thermantarcticus that potentially could survive space transport is one main key point to support this theory.

\section{Genome of P. thermantarcticus}

The P. thermantarcticus M1 genome was sequenced in 2014 by the U.S. Department of Energy Joint Genome Institute. The DOE mission is to advance genomics linked to clean energy production and environmental cleaning and characterization [108]. The P. thermantarcticus M1 genome was obtained under a program entitled: "Genomic Encyclopedia of Type Strains, Phase III the genomes of soil and plant-associated and newly described type strains" (https://img.jgi.doe.gov/cgi-bin/m/main.cgi). The sequencing method applied was Illumina HiSeq 2500-1TB, and the NCBI Bioproject Accession number is PRJNA323262. The total number of sequenced bases was 3,448,881, of which $85.19 \%$ are coding bases; the DNA C + G \% emerged at $43.63 \%$ and was calculated as a count of Gs and Cs divided by the total number of bases. The total genes number was 3714, of which the protein-coding genes were $96.85 \%$, and the residual $3.15 \%$ were RNA genes. Protein-coding genes with function prediction were $2783(79.93 \%)$, while those without function prediction were 814 .

Enzyme-coding genes were 988, and protein-coding genes connected to Kyoto Encyclopedia of Genes and Genomes (KEGG) pathways database were 1058 (Figure 4). KEGG is a database that incorporates genomic, systemic, functional, and chemical information [109]. 


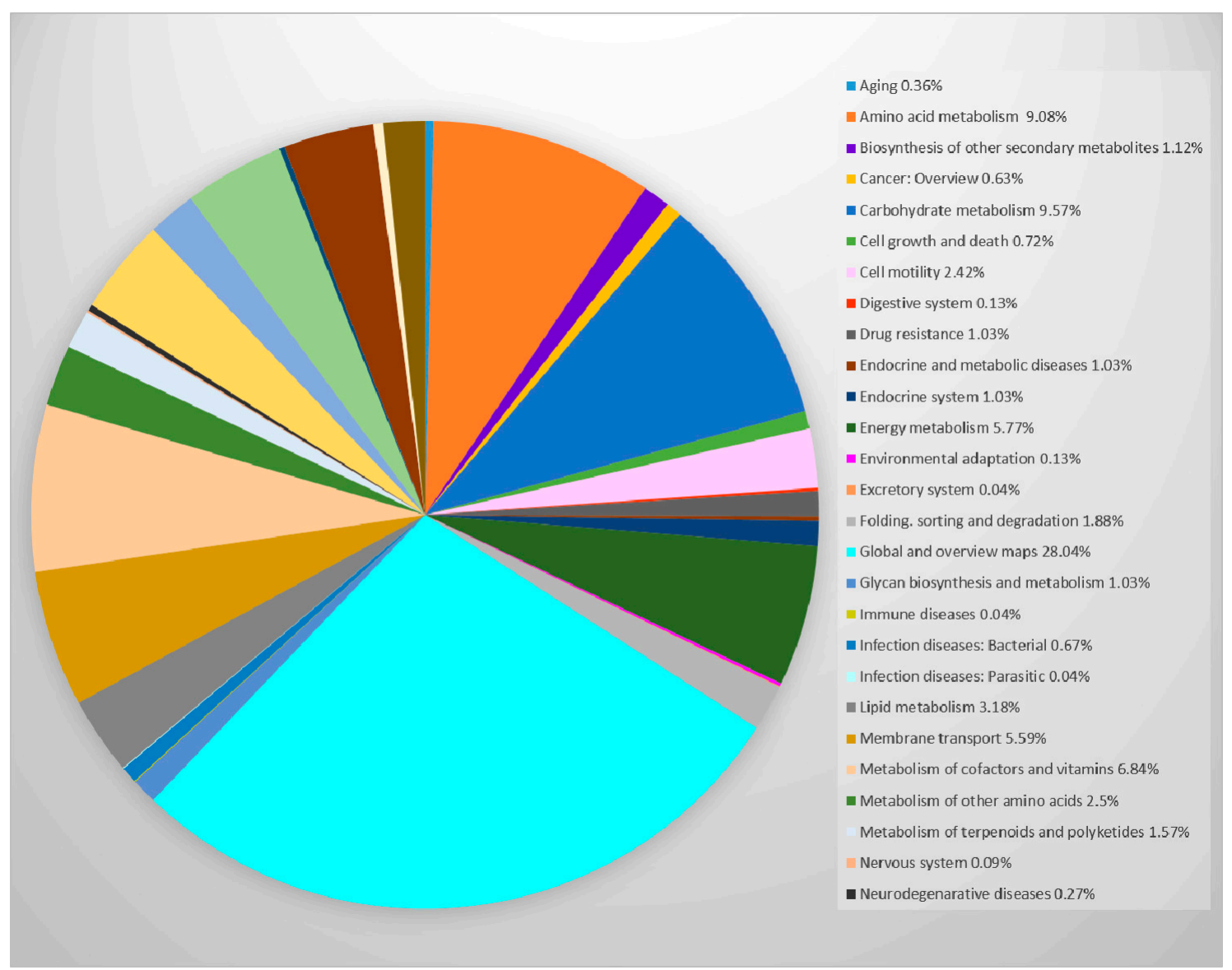

Figure 4. Kyoto Encyclopedia of Genes and Genomes (KEGG) categories of the P. thermantarcticus M1 genome.

As show in Figure 4, the category "Global and overview maps" occupies the highest percentage of KEGG categories in which $P$. thermantarcticus genome results are divided and relies on basal metabolism reactions such as 2-Oxocarboxylic acid metabolism; carbon metabolism; biosynthesis of antibiotics, amino acids, and secondary metabolites; degradation of aromatic compounds; fatty acid metabolism; metabolic pathways; etc. Moreover, the genes related to the carbohydrate, aminoacid, vitamin, energy metabolisms, membrane transport and signal transduction are also present. Protein-coding genes in the internal cluster were 852, while those in the chromosomal cassette were 3566. Genes found in biosynthetic clusters were 111; fused protein-coding genes were 281; protein-coding genes coding signal peptides were 108; protein-coding genes coding transmembrane proteins were 847.

Genome investigation of $P$. thermantarcticus M1 showed an aerobic metabolism for the presence of ubiquinol oxidation with an oxygen (with proton transport) pathway (Pathway OID 768), as confirmed by the experimental data [8]; in addition, the genome revealed the possibility to set up growth in anaerobic conditions thanks to the presence of a metabolism in which nitrate $\left(\mathrm{NO}_{3}{ }^{-}\right)$becomes the electron acceptor for respiration in the dissimilatory nitrate reduction pathway (Pathway OID 764) and the presence of the gene coding for the alcohol dehydrogenase, class IV.

$P$. thermantarcticus M1 is a motile, rod-shaped bacterium, as previously reported [8]. These morphological and mechanical properties have found confirmation in the genome reading. Indeed, there are many genes coding for the cell shape (rod shape-determining protein RodA), chemotaxis, and flagellar biosynthesis proteins.

From a chemotaxonomic point of view, Nicolaus et al. [8] reported for P. thermantarcticus M1 three phospholipids and one phosphoglycolipid, as major components. Genes coding for cardiolipin synthase and cardiolipin synthetase 2 (EC:2.7.8) were found. 
Starting from the genome analysis, $P$. thermantarcticus $M 1$ possesses a prototroph metabolism for L-aspartate, L-alanine, glycine, L-glutamate, L-glutamine, L-asparagine, Coenzyme A, and L-methionine synthesis while, an auxotroph metabolism emerged for L-phenylalanine, L-tryptophan, L-tyrosine, L-histidine, L-arginine, L-leucine, and L-serine synthesis.

P. thermantarcticus M1 produces spores [8], and they represent a useful biological system that allows the microorganism to survive under extreme environmental conditions, including space simulation, as recently reported [12-14]. The genome examination highlighted several genes involved in the sporulation system, ranging from genes coding for sporulation proteins and lipoprotein, prespore-specific regulator, to spore germination proteins.

Concerning sugars metabolism, sucrose-, glucose-, fructose-, and xylose-utilizing pathways were pointed out in the genome. In particular, sucrose conversion to fructose and glucose 6-phosphate and sucrose hydrolysis pathways were reported; in addition, evidence of metabolic dissimilation of glucose, the "Embden Meyerhof pathway" giving pyruvic acid, emerged; the fructose and xylose metabolisms dealing with D-Fructose 6-phosphate formation from D-fructose and D-xylose conversion to D-xylulose 5-phosphate were also found. Moreover, $P$. thermantarcticus M1 utilizes glucose, trehalose, and xylose for growth, only weakly maltose and sucrose, while it does not utilize cellobiose, proprionate, citrate, and dextrin [8]. Furthermore, the ability to utilize mannose for growth resulted in Manca et al. [11]; in addition, xylan, arabinose, galactose, fructose can be added to the above-reported list of sugar utilization for growth as deducible from Lama et al. [55]. Complementary information of the sugar metabolism comes from the presence in the genome of the carbohydrate $\mathrm{ABC}$ transporter membrane protein 2_CUT1 family, protein 1_CUT1 family, and substrate-binding protein_CUT1 family.

P. thermantarcticus $\mathrm{M} 1$ was described as an exopolysaccharide producer, when grown with mannose as a sole carbon and energy source [11]. The secretion of polymers out of the cell represents an ecological manner to better support the extreme conditions in which extremophilic microorganisms live [110]. In fact, the main ecological role of exopolysaccharides is their protective nature: EPSs, generating a layer around the cell, furnish a defense mechanism with respect to extremes of temperature and salinity or potential predators. They are indispensable in film construction, in the system of surface adhesion, and in nutrient uptake [110-112]. Genomic evidence was found in the asserted metabolic pathway concerning acetyl-CoA assimilation via the glyoxylate cycle, responsible for the biosynthesis of polysaccharides during gluconeogenesis.

Dipasquale et al. [80] described a proteolytic activity detected in the cell-free supernatant. Experimental results recommended that the enzyme belongs to the serine protease family (EC. 3.4.21) and had a presumed molecular mass of about $42 \mathrm{kDa}$. The analysis of genes coding for proteins revealed a huge number of genes promoting catalytic activities able to hydrolyze peptide bonds. Among them, a gene coding for serine protease S1-C subfamily, containing the C-terminal PDZ domain, was noted, for which the exact molecular weight was $43 \mathrm{kDa}$, by confirming the experimental results.

$P$. thermantarcticus M1 produced an intracellular xylose isomerase showing a molecular mass of about $47 \mathrm{kDa}$, with an isoelectric point of 4.8. Lama et al. [61], going over the genome, detected the presence of a gene encoding for the abovementioned activity.

In addition, $P$. thermantarcticus M1 produced, in the cell-free supernatant, xylanase and $\beta$-xylosidase activities [55]. The genome study confirmed the experimental evidence for hemicellulose activities: Both genes encoding for endo-1,4 beta-xylanase and xylan 1,4-beta-xylosidase have been found.

At present, the $P$. thermantarcticus M1 genome investigation indicates the presence of many other biotechnologically interesting potentialities not yet studied. Indeed, at the time of writing, there is no experimental evidence relying on the presence of urease, pullulanase, beta-fructofuranosidase, endoglucanase, and polyhydroxyalkanoate synthase activities, which, by contrast, have been reported in genome sequencing. 
Therefore, knowledge of the $P$. thermantarcticus M1 genome sequence supports the experimental results collected up to now; on the other hand, this suggests that different other research activities coupled with modern fermentation systems and innovative molecular biology techniques could open up new possible scenarios to better exploit the potential of this microorganism.

For instance, starting from metabolic pathways and the presence of specific genes, the search for the best enzymatic activity-inducing substrates could be performed more easily; in addition, gene cloning strategies in a suitable engineered host could improve the catalyst and the corresponding hydrolysis products' productivities. In this view, in the literature, there are many examples of hemicellulolitic genes cloning aiming at higher activity expression [113]. The gene coding for a $\beta$-xylosidase activity present in the genome of the thermophilic Geobacillus stearothermophilus microorganism was cloned and expressed in E. coli. In addition, an amino acid substitution at position 509 extended the enzymatic hydrolysis reaction to the long-chain xylo-oligomers [53].

\section{Conclusions}

Parageobacillus thermantarcticus strain M1 has come a long way from being a new Antarctic thermophile to a potential microbial cell factory for the production of industrially important products with great bioeconomic value, especially in the green chemistry field. There are still many opportunities for the improvement of the M1 system as a microbial cell factory, since its molecular toolbox is still relatively unexplored. An expansion of said toolbox would open to further potential, especially in terms of genetic and metabolic engineering. At present, the $P$. thermantarcticus genome investigation indicates the presence of many other biotechnologically interesting potentialities not yet studied, such as the presence of urease, pullulanase, beta-fructofuranosidase, endoglucanase, and polyhydroxyalkanoate synthase activities.

Experimental data and previous publications revealed the extraordinary enzymatic pattern of this bacterium: an extracellular xylanase, a beta-xylosidase, an intracellular xylose/glucose isomerase, and a protease that makes this thermophile of great potential in biotechnological applications, not only for industrial biocatalysis but also for bioprocessing aims. In fact, the optimization of enzymatic procedures for the conversion of waste lignocellulosic materials in high added value molecules using the xylanolytic enzymatic set of $P$. thermantarcticus produced extremely innovative results. These enzymes, which were involved in the enzymatic digestions of hemicellulose fraction from crop residue, have been used for the bioconversion of agrowaste into xylo-oligomers and fermentable sugars. The high thermoactivity and thermostability of the enzymatic pattern studied and the stability over a wide range of $\mathrm{pH}$ values suggest that the enzymes from $P$. thermantarcticus could be a good candidate for various biotechnological applications. In fact, considering the great importance in the industrial and commercial field of the heat-stable enzymes, the search for new microbial sources of such enzymes grows continually, also because the demand for the development of a more eco-compatible industry is becoming increasingly strong.

Author Contributions: I.F. and L.L. (Luigi Leone) wrote the genome paragraph; L.L. (Licia Lama) wrote the paragraph concerning the enzymes; P.D.D. and I.R. wrote the astrobiology paragraph; A.T. wrote a paragraph concerning the production of xylo-oligosaccharides; A.P. wrote the paragraph on the phylogenetic Re-Assessment. I.F., A.P. and B.N. conceived the structure of the presented review.

Funding: This research was funded by PNRA16_00020.

Acknowledgments: For the genoma sequencing of $P$. thermantarcticus, the authors thank "The Genomic Encyclopedia of Bacteria and Archaea (GEBA) projects": this project conducted by the U.S. Department of Energy Joint Genome Institute is supported by the Office of Science of the U.S. Department of Energy under Contract No. DE-AC02-05CH11231.

Conflicts of Interest: The authors declare no conflict of interest. 


\section{References}

1. Kambourova, M.; Radchenkova, N.; Tomova, I.; Bojadjieva, I. Thermophiles as a Promising Source of Exopolysaccharides with Interesting Properties. In Biotechnology of Extremophiles; Rampelotto, P.H., Ed.; Grand Challenges in Biology and Biotechnology; Springer International Publishing: Cham, Switzerland, 2016; pp. 117-139.

2. Kirk, O.; Borchert, T.V.; Fuglsang, C.C. Industrial enzyme applications. Curr. Opin. Biotechnol. 2002, 13, 345-351. [CrossRef]

3. Van Beilen, J.B.; Li, Z. Enzyme technology: An overview. Curr. Opin. Biotechnol. 2002, 13, 338-344. [CrossRef]

4. Zeigler, D.R. The Geobacillus paradox: Why is a thermophilic bacterial genus so prevalent on a mesophilic planet? Microbiology 2014, 160, 1-11. [CrossRef] [PubMed]

5. Muñoz, P.A.; Flores, P.A.; Boehmwald, F.A.; Blamey, J.M. Thermophilic bacteria present in a sample from Fumarole Bay, Deception Island. Antarct. Sci. 2011, 23, 549-555. [CrossRef]

6. Vieille, C.; Zeikus, G.J. Hyperthermophilic enzymes: Sources, uses, and molecular mechanisms for thermostability. Mol. Biol. Rev. 2001, 65, 1-43. [CrossRef]

7. Nicolaus, B.; Lama, L.; Gambacorta, A. Thermophilic bacillus isolated from Antarctic environments. In Thermophilic Bacillus Isolates from Antarctic Environments Applications and systematics of Bacillus and Relatives; Berkeley, R., Heyndrickx, M., Logan, M., de Vos, P., Eds.; Blackwell: Oxford, UK, 2002; pp. 47-63.

8. Nicolaus, B.; Lama, L.; Esposito, E.; Manca, M.C.; di Prisco, G.; Gambacorta, A. "Bacillus thermoantarcticus" sp. nov., from Mount Melbourne, Antarctica: A novel thermophilic species. Polar Biol. 1996, 16, 101-104.

9. Lama, L.; Tramice, A.; Finore, I.; Anzelmo, G.; Calandrelli, V.; Pagnotta, E.; Tommonaro, G.; Poli, A.; Di Donato, P.; Nicolaus, B.; et al. Degradative actions of microbial xylanolytic activities on hemicelluloses from rhizome of Arundo donax. AMB Express 2014, 4, 55-64. [CrossRef]

10. Finore, I.; Poli, A.; Di Donato, P.; Lama, L.; Trincone, A.; Fagnano, M.; Mori, M.; Nicolaus, B.; Tramice, A. The hemicellulose extract from Cynara cardunculus: A source of value-added biomolecules produced by xylanolytic thermozymes. Green Chem. 2016, 18, 2460-2472. [CrossRef]

11. Manca, M.C.; Lama, L.; Improta, R.; Esposito, E.; Gambacorta, A.; Nicolaus, B. Chemical Composition of Two Exopolysaccharides from Bacillus thermoantarcticus. Appl. Environ. Microbiol. 1996, 62, 3265-3269.

12. Mastascusa, V.; Romano, I.; Di Donato, P.; Poli, A.; Della Corte, V.; Rotundi, A.; Bussoletti, E.; Quarto, M.; Pugliese, M.; Nicolaus, B. Extremophiles Survival to Simulated Space Conditions: An Astrobiology Model Study. Orig. Life Evol. Biosph. 2014, 44, 231-237. [CrossRef]

13. Di Donato, P.; Romano, I.; Mastascusa, V.; Poli, A.; Orlando, P.; Pugliese, M.; Nicolaus, B. Survival and Adaptation of the Thermophilic Species Geobacillus thermantarcticus in Simulated Spatial Conditions. Orig. Life Evol. Biosph. 2018, 48, 141-158. [CrossRef] [PubMed]

14. Romano, I.; De Angelis, A.; Poli, A.; Ragni, P.; Lilla, L.; Zito, G.; Nicolaus, B.; De Luca, A.C.; Di Donato, P. Resistance and Raman spectroscopy analysis of Parageobacillus thermantarcticus spores after $\gamma$-ray exposure. Extremophiles 2018, 22, 931-941. [CrossRef] [PubMed]

15. Lu, H.; Villada, J.C.; Lee, P.K.H. Modular Metabolic Engineering for Biobased Chemical Production. Trends Biotechnol. 2019, 37, 152-166. [CrossRef] [PubMed]

16. Nicolaus, B.; Lama, L.; Esposito, E.; Manca, M.C.; di Prisco, G.; Gambacorta, A. Validation of publication of new names and new combinations previously effectively published outside the IJSEM. Int. J. Syst. Evol. Microbiol. 2005, 55, 1743-1745.

17. Chen, X.G.; Stabnikova, O.; Tay, J.H.; Wang, J.Y.; Tay, S.T.L. Thermoactive extracellular proteases of Geobacillus caldoproteolyticus, sp. nov., from sewage sludge. Extremophiles 2004, 8, 489-498. [CrossRef]

18. Ash, C.; Farrow, J.A.E.; Wallbanks, S.; Collins, M.D. Phylogenetic heterogeneity of the genus Bacillus revealed by comparative analysis of small-subunit-ribosomal RNA sequences. Lett. Appl. Microbiol. 1991, 13, $202-206$. [CrossRef]

19. Rainey, F.A.; Fritze, D.; Stackebrandt, E. The phylogenetic diversity of thermophilic members of the genus Bacillus as revealed by $16 \mathrm{~S}$ rDNA analysis. FEMS Microbiol. Lett. 1994, 115, 205-211. [CrossRef] 
20. Nazina, T.N.; Tourova, T.P.; Poltaraus, A.B.; Novikova, E.V.; Grigoryan, A.A.; Ivanova, A.E.; Lysenko, A.M.; Petrunyaka, V.V.; Osipov, G.A.; Belyaev, S.S.; et al. Taxonomic study of aerobic thermophilic bacilli: descriptions of Geobacillus subterraneus gen. nov., sp. nov. and Geobacillus uzenensis sp. nov. from petroleum reservoirs and transfer of Bacillus stearothermophilus, Bacillus thermocatenulatus, Bacillus thermoleovorans, Bacillus kaustophilus, Bacillus thermodenitrificans to Geobacillus as the new combinations G. stearothermophilus, G. th. Int. J. Syst. Evol. Microbiol. 2001, 51, 433-446. [CrossRef]

21. Scholz, T.; Demharter, W.; Hensel, R.; Kandler, O. Bacillus pallidus sp. nov., a new thermophilic species from sewage. Syst. Appl. Microbiol. 1987, 9, 91-96. [CrossRef]

22. Ahmad, S.; Scopes, R.K.; Rees, G.N.; Patel, B.K.C. Saccharococcus caldoxylosilyticus sp. nov., an obligately thermophilic, xylose-utilizing, endospore-forming bacterium. Int. J. Syst. Evol. Microbiol. 2000, 50, 517-523. [CrossRef]

23. Caccamo, D.; Gugliandolo, C.; Stackebrandt, E.; Maugeri, T.L. Bacillus vulcani sp. nov., a novel thermophilic species isolated from a shallow marine hydrothermal vent. Int. J. Syst. Evol. Microbiol. 2000, 50, 2009-2012. [CrossRef] [PubMed]

24. Fortina, M.G.; Mora, D.; Schumann, P.; Parini, C.; Manachini, P.L.; Stackebrandt, E. Reclassification of Saccharococcus caldoxylosilyticus as Geobacillus caldoxylosilyticus (Ahmad et al. 2000) comb. nov. Int. J. Syst. Evol. Microbiol. 2001, 51, 2063-2071. [CrossRef] [PubMed]

25. Banat, I.M.; Marchant, R.; Rahman, T.J. Geobacillus debilis sp. nov., a novel obligately thermophilic bacterium isolated from a cool soil environment, and reassignment of Bacillus pallidus to Geobacillus pallidus comb. nov. Int. J. Syst. Evol. Microbiol. 2004, 54, 2197-2201. [CrossRef] [PubMed]

26. Nazina, T.N.; Lebedeva, E.V.; Poltaraus, A.B.; Tourova, T.P.; Grigoryan, A.A.; Sokolova, D.S.; Lysenko, A.M.; Osipov, G.A. Geobacillus gargensis sp. nov., a novel thermophile from a hot spring, and the reclassification of Bacillus vulcani as Geobacillus vulcani comb. nov. Int. J. Syst. Evol. Microbiol. 2004, 54, 2019-2024. [CrossRef] [PubMed]

27. Miñana-Galbis, D.; Pinzón, D.L.; Lorén, J.G.; Manresa, À.; Oliart-Ros, R.M. Reclassification of Geobacillus pallidus (Scholz et al. 1988) Banat et al. 2004 as Aeribacillus pallidus gen. nov., comb. nov. Int. J. Syst. Evol. Microbiol. 2010, 60, 1600-1604. [CrossRef]

28. Sung, M.H.; Kim, H.; Bae, J.W.; Rhee, S.K.; Jeon, C.O.; Kim, K.; Kim, J.J.; Hong, S.P.; Lee, S.G.; Yoon, J.H.; et al. Geobacillus toebii sp. nov., a novel thermophilic bacterium isolated from hay compost. Int. J. Syst. Evol. Microbiol. 2002, 52, 2251-2255. [CrossRef] [PubMed]

29. Kuisiene, N.; Raugalas, J.; Chitavichius, D. Geobacillus lituanicus sp. nov. Int. J. Syst. Evol. Microbiol. 2004, 54, 1991-1995. [CrossRef] [PubMed]

30. Schäffer, C.; Franck, W.L.; Scheberl, A.; Kosma, P.; McDermott, T.R.; Messner, P. Classification of isolates from locations in Austria and Yellowstone National Park as Geobacillus tepidamans sp. nov. Int. J. Syst. Evol. Microbiol. 2004, 54, 2361-2368. [CrossRef] [PubMed]

31. Nazina, T.N.; Sokolova, D.S.; Grigoryan, A.A.; Shestakova, N.M.; Mikhailova, E.M.; Poltaraus, A.B.; Tourova, T.P.; Lysenko, A.M.; Osipov, G.A.; Belyaev, S.S. Geobacillus jurassicus sp. nov., a new thermophilic bacterium isolated from a high-temperature petroleum reservoir, and the validation of the Geobacillus species. Syst. Appl. Microbiol. 2005, 28, 43-53. [CrossRef]

32. Coorevits, A.; Dinsdale, A.E.; Halket, G.; Lebbe, L.; de Vos, P.; Van Landschoot, A.; Logan, N.A. Taxonomic revision of the genus Geobacillus: Emendation of Geobacillus, G. stearothermophilus, G. jurassicus, G. toebii, G. thermodenitrificans and G. thermoglucosidans (nom. corrig., formerly 'thermoglucosidasius'); transfer of Bacillus thermantarcticus to the genus as G. thermantarcticus comb. nov.; proposal of Caldibacillus debilis gen. nov., comb. nov.; transfer of G. tepidamans to Anoxybacillus as A. tepidamans comb. nov.; and proposal of Anoxybacillus caldiproteolyticus sp. nov. Int. J. Syst. Evol. Microbiol. 2012, 62, 1470-1485. [CrossRef]

33. Claus, D.; Berkeley, R.C.W. Genus Bacillus Cohn 1872. In Bergey's Manual of Systematic Bacteriology; Sneath, P.H.A., Mair, N.S., Sharpe, M.E., Holt, J.G., Eds.; Williams \& Wilkins: Baltimore, MD, USA, 1986; Volume 2, pp. 1105-1140.

34. Zeigler, D.R. Application of a recN sequence similarity analysis to the identification of species within the bacterial genus Geobacillus. Int. J. Syst. Evol. Microbiol. 2005, 5, 1171-1179. [CrossRef] [PubMed]

35. Aliyu, H.; Lebre, P.; Blom, J.; Cowan, D.; De Maayer, P. Phylogenomic re-assessment of the thermophilic genus Geobacillus. Syst. Appl. Microbiol. 2016, 39, 527-533. [CrossRef] [PubMed] 
36. Kumar, R.; Singh, S.; Singh, O.V. Bioconversion of lignocellulosic biomass: Biochemical and molecular perspectives. J. Ind. Microbiol. Biotechnol. 2008, 35, 377-391. [CrossRef] [PubMed]

37. Jain, I.; Kumar, V.; Satyanarayana, T. Applicability of recombinant beta-xylosidase from the extremely thermophilic bacterium Geobacillus thermodenitrificans in synthesizing alkylxylosides. Bioresour. Technol. 2014, 170, 462-469. [CrossRef] [PubMed]

38. Subramaniyan, S.; Prema, P. Cellulase-free xylanases from Bacillus and other microorganisms. FEMS Microbiol. Lett. 2000, 183, 1-7. [CrossRef] [PubMed]

39. Shao, W.; Xue, Y.; Wu, A.; Kataeva, I.; Pei, J.; Wu., H.; Wiegel, J. Characterization of a Novel beta-xylosidase, XylC, from Thermoanaerobacterium saccharolyticum JW/SL-YS485. Appl. Environ. Microbiol. 2011, 77, 719-726. [CrossRef] [PubMed]

40. Anand, A.; Kumar, V.; Satyanarayana, T. Characteristics of thermostable endoxylanase and $\beta$-xylosidase of the extremely thermophilic bacterium Geobacillus thermodenitrificans TSAA1 and its applicability in generating xylooligosaccharides and xylose from agro-residues. Extremophiles 2013, 17, 357-366. [CrossRef]

41. Shi, H.; Li, X.; Gu, H.; Zhang, Y.; Huang, Y.M.; Wang, L.; Wang, F. Biochemical properties of a novel thermostable and highly xylose-tolerant $\beta$-xylosidase/ $\alpha$-arabinosidase from Thermotoga thermarum. Biotechnol. Biofuels 2013, 6, 27. [CrossRef]

42. Khasin, A.; Alchanati, I.; Shoham, Y. Purification and characterization of a thermostable xylanase from Bacillus stearothermophilus T-6. Appl. Environ. Microbiol. 1993, 59, 1725-1730.

43. Beg, Q.; Kapoor, M.; Mahajan, L.; Hoondal, G.S. Microbial xylanases and their industrial applications: A review. Appl. Microbiol. Biotechnol. 2001, 56, 326-338. [CrossRef]

44. Polizeli, M.L.T.M.; Rizzatti, A.C.S.; Monti, R.; Terenzi, H.F.; Jorge, J.A.; Amorim, D.S. Xylanases from fungi: Properties and industrial applications. Appl. Microbiol. Biotechnol. 2005, 67, 577-591. [CrossRef] [PubMed]

45. FitzPatrick, M.; Champagne, P.; Cunningham, M.F.; Whitney, R.A. A biorefinery processing perspective: Treatment of lignocellulosic materials for the production of value-added products. Bioresour. Technol. 2010, 101, 8915-8922. [CrossRef] [PubMed]

46. Yang, H.J.; Xie, C.Y. Assessment of fibrolytic activities of 18 commercial enzyme products and their abilities to degrade the cell wall fraction of corn stalks in in vitro enzymatic and ruminal batch cultures. Anim. Feed Sci. Technol. 2010, 159, 110-121. [CrossRef]

47. Chadha, B.S.; Kaur, B.; Basotra, N.; Tsang, A.; Pandey, A. Thermostable xylanases from thermophilic fungi and bacteria: Current perspective. Bioresour. Technol. 2019, 277, 195-203. [CrossRef] [PubMed]

48. Daas, M.J.A.; Murciano Martínez, P.; van de Weijer, A.H.P.; van der Oost, J.; de Vos, W.M.; Kabel, M.A.; van Kranenburg, R. Biochemical characterization of the xylan hydrolysis profile of the extracellular endoxylanase from Geobacillus thermodenitrificans T1. BMC Biotechnol. 2017, 17, 44. [CrossRef]

49. Bhalla, A.; Bischoff, K.M.; Uppugundla, N.; Balan, V.; Sani, R.K. Novel thermostable endo-xylanase cloned and expressed from bacterium Geobacillus sp. WSUCF1. Bioresour. Technol. 2014, 165, 314-318. [CrossRef] [PubMed]

50. Bibra, M.; Kunreddy, V.; Sani, R. Thermostable Xylanase Production by Geobacillus sp. strain DUSELR13, and Its Application in Ethanol Production with Lignocellulosic Biomass. Microorganisms 2018, 6, 93. [CrossRef]

51. Marcolongo, L.; La Cara, F.; Morana, A.; Di Salle, A.; del Monaco, G.; Paixão, S.M.; Alves, L.; Ionata, E. Properties of an alkali-thermo stable xylanase from Geobacillus thermodenitrificans A333 and applicability in xylooligosaccharides generation. World J. Microbiol. Biotechnol. 2015, 31, 633-648. [CrossRef]

52. Shallom, D.; Shoham, Y. Microbial hemicellulases. Curr. Opin. Microbiol. 2003, 6, 219-228. [CrossRef]

53. Ratnadewi, A.A.; Fanani, M.; Kurniasih, S.D.; Sakka, M.; Wasito, E.B.; Sakka, K.; Nurachman, Z.; Puspaningsih, N.N. $\beta$-D-Xylosidase from Geobacillus thermoleovorans IT-08: Biochemical Characterization and Bioinformatics of the Enzyme. J. Ind. Microbiol. Biotechnol. 2014, 41, 65-74. [CrossRef]

54. Sari, B.; Faiz, O.; Genc, B.; Sisecioglu, M.; Adiguzel, A.; Adiguzel, G. New xylanolytic enzyme from Geobacillus galactosidasius BS61 from a geothermal resource in Turkey. Int. J. Biol. Macromol. 2018, 119, 1017-1026. [CrossRef] [PubMed]

55. Lama, L.; Calandrelli, V.; Gambacorta, A.; Nicolaus, B. Purification and characterization of thermostable xylanase and $\beta$-xylosidase by the thermophilic bacterium Bacillus thermantarcticus. Res. Microbiol. 2004, 155, 283-289. [CrossRef] [PubMed] 
56. Duarte, A.W.F.; dos Santos, J.A.; Vianna, M.V.; Vieira, J.M.F.; Mallagutti, V.H.; Inforsato, F.J.; Wentzel, L.C.P.; Lario, L.D.; Rodrigues, A.; Pagnocca, F.C.; et al. Cold-adapted enzymes produced by fungi from terrestrial and marine Antarctic environments. Crit. Rev. Biotechnol. 2018, 38, 600-619. [CrossRef]

57. Watanabe, T.; Suzuki, K.; Sato, I.; Morita, T.; Koike, H.; Shinozaki, Y.; Ueda, H.; Koitabashi, M.; Kitamoto, H.K. Simultaneous bioethanol distillery wastewater treatment and xylanase production by the phyllosphere yeast Pseudozyma antarctica GB-4(0). AMB Express 2015, 5, 36. [CrossRef] [PubMed]

58. Finore, I.; Orlando, P.; Di Donato, P.; Leone, L.; Nicolaus, B.; Poli, A. Nesterenkonia aurantiaca sp. nov., an alkaliphilic actinobacterium isolated from Antarctica. Int. J. Syst. Evol. Microbiol. 2016, 66, 1554-1560. [CrossRef] [PubMed]

59. Parker, K.; Salas, M.; Nwosu, V.C. High fructose corn syrup: Production, uses and public health concerns. Biotechnol. Molecul. Biol. Rev. 2010, 5, 71-78.

60. Lee, S.M.; Jellison, T.; Alper, H.S. Directed Evolution of Xylose Isomerase for Improved Xylose Catabolism and Fermentation in the Yeast Saccharomyces cerevisiae. Appl. Environ. Microbiol. 2012, 78, 5708-5716. [CrossRef] [PubMed]

61. Lama, L.; Nicolaus, B.; Calandrelli, V.; Romano, I.; Basile, R.; Gambacorta, A. Purification and characterization of thermostable xylose(glucose) isomerase from Bacillus thermoantarcticus. J. Ind. Microbiol. Biotechnol. 2001, 27, 234-240. [CrossRef] [PubMed]

62. Fernandes, P. Enzymes in Food Processing: A Condensed Overview on Strategies for Better Biocatalysts. Enzym. Res. 2010, 2010, 862537. [CrossRef]

63. Bhosale, S.H.; Rao, M.B.; Deshpande, V.V. Molecular and Industrial Aspects of Glucose Isomerase. Microbiol. Rev. 1996, 60, 280-300.

64. Lama, L.; Nicolaus, B.; Calandrelli, V.; Esposito, E.; Gambacorta, A. Xylanase produced by Bacillus thermoantarcticus, a new thermophilic bacillus. Ann. N. Y. Acad. Sci. Pap. 1996, 799, 284-289. [CrossRef]

65. Brown, S.H.; Sjoholm, C.; Kelly, R.M. Purification and characterization of a highly thermostable glucose isomerase produced by the extremely thermophilic eubacterium, Thermotoga maritima. Biotechnol. Bioeng. 1993, 41, 878-886. [CrossRef] [PubMed]

66. Dekker, K.; Sugiura, A.; Yamagata, H.; Sakaguchi, K.; Udaka, S. Efficient production of thermostable Thermus thermophilus xylose isomerase in Escherichia coli and Bacillus brevis. Appl. Microbiol. Biotechnol. 1992, 36, 727-732. [CrossRef]

67. Hess, J.M.; Tchernajenko, V.; Vieille, C.; Zeikus, J.G.; Kelly, R.M. Thermotoga neapolitana Homotetrameric Xylose Isomerase Is Expressed as a Catalytically Active and Thermostable Dimer in Escherichia coli. Appl. Environ. Microbiol. 1998, 64, 2357-2360. [PubMed]

68. Suekane, M.M.; Tamura, M.; Tomimura, C. Physico-chemical and Enzymatic Properties of Purified Glucose Isomerases from Streptomyces olivochromogenes and Bacillus stearothermophilus. Agric. Biol. Chem. 1978, 42, 909-917. [CrossRef]

69. Inyang, C.U.; Gebhart, U.; Obi, S.K.C.; Bisswanger, H. Isolation and characterization of a D-glucose/xylose isomerase from a new thermophilic strain Streptomyces sp. (PLC). Appl. Microbiol. Biotechnol. 1995, 43, 632-638. [CrossRef]

70. Lee, C.; Zeikus, G. Purification and characterization of thermostable glucose isomerase from Clostridium thermosulfurogenes and Thermoanaerobacter strain B6A. Biochem. J. 1991, 273, 565-571. [CrossRef]

71. Lee, Y.E.; Ramesh, M.V.; Zeikus, J.G. Cloning, sequencing and biochemical characterization of xylose isomerase from Thermoanaerobacterium saccharolyticum strain B6A-RI. J. Gen. Microbiol. 1993, 139, 1227-1234. [CrossRef]

72. Srih-Belghith, K.; Bejar, S. A thermostable glucose isomerase having a relatively low optimum pH: Study of activity and molecular cloning of the corresponding gene. Biotechnol. Lett. 1998, 20, 553-556. [CrossRef]

73. Vieille, C.; Hess, J.M.; Kelly, R.M.; Zeikus, J.G. XylA cloning and sequencing and biochemical characterization of xylose isomerase from Thermotoga neapolitana. Appl. Environ. Microbiol. 1995, 61, 1867-1875.

74. Konak, L.; Kolcuoğlu, Y.; Ozbek, E.; Colak, A.; Ergenoglu, B. Purification and characterization of an extremely stable glucose isomerase from Geobacillus thermodenitrificans TH2. Appl. Biochem. Microbiol. 2014, 50, 25-29. [CrossRef]

75. Chauthaiwale, J.; Rao, M. Production and Purification of Extracellular D-Xylose Isomerase from an Alkaliphilic, Thermophilic Bacillus sp. Appl. Environ. Microb. 1994, 60, 4495-4499. 
76. Kumar, C.G.; Takagi, H. Microbial alkaline proteases: from a bioindustrial viewpoint. Biotechnol. Adv. 1999, 17, 561-594. [CrossRef]

77. Rahman, R.N.Z.A.; Razak, C.N.; Ampon, K.; Basri, M.; Zin, W.M.; Yunus, W.; Salleh, A.B. Purification and characterization of a heat-stable alkaline protease from Bacillus stearothermophilus F1. Appl. Microbiol. Biotechnol. 1994, 40, 822-827. [CrossRef]

78. Hawumba, J.F.; Theron, J.; Brözel, V.S. Thermophilic protease-producing Geobacillus from Buranga hot springs in Western Uganda. Curr. Microbiol. 2002, 45, 144-150. [CrossRef]

79. Contesini, F.J.; de Melo, R.R.; Sato, H.H. An overview of Bacillus proteases: From production to application. Crit. Rev. Biotechnol. 2018, 38, 321-334. [CrossRef]

80. Dipasquale, L.; Calandrelli, V.; Romano, I.; Nicolaus, B.; Gambacota, A.; Lama, L. Purification and characterisation of a highly thermostable extracellular protease from Bacillus thermantarcticus, strain M1. Ann. Microbiol. 2008, 58, 253-259. [CrossRef]

81. Sako, Y.; Croocker, P.C.; Ishida, Y. An extremely heat-stable extracellular proteinase (aeropyrolysin) from the hyperthermophilic archaeon Aeropyrum pernix K. FEBS Lett. 1997, 415, 329-334. [CrossRef]

82. Johnvesly, B.; Naik, G.R. Studies on production of thermostable alkaline protease from thermophilic and alkaliphilic Bacillus sp. JB-99 in a chemically defined medium. Proc. Biochem. 2001, 37, 139-144. [CrossRef]

83. Zhu, W.; Cha, D.; Cheng, G.; Peng, Q.; Shen, P. Purification and characteriztion of a thermostable protease from a newly isolated Geobacillus sp. YMTC 1049. Enzym. Microbiol. Technol. 2007, 40, 1592-1597. [CrossRef]

84. Thebti, W.; Riahi, Y.; Belhadj, O. Purification and Characterization of a New Thermostable, Haloalkaline, Solvent Stable, and Detergent Compatible Serine Protease from Geobacillus toebii strain LBT 77. BioMed Res. Int. 2016, 2016, 9178962. [CrossRef] [PubMed]

85. Zhou, M.Y.; Wang, G.L.; Li, D.; Zhao, D.L.; Qin, Q.L.; Chen, X.L.; Chen, B.; Zhou, B.C.; Zhang, X.Y.; Zhang, Y.Z. Diversity of Both the Cultivable Protease-Producing Bacteria and Bacterial Extracellular Proteases in the Coastal Sediments of King George Island, Antarctica. PLoS ONE 2013, 8, e79668. [CrossRef] [PubMed]

86. Vazquez, S.C.; Coria, S.H.; Mac Cormack, W.P. Extracellular proteases from eight psychrotolerant antarctic strains. Microbiol. Res. 2004, 159, 157-166. [CrossRef] [PubMed]

87. Dhiman, S.S.; Sharma, J.; Battan, B. Industrial applications and future prospects of microbial xylanases: A review. BioResources 2008, 3, 1377-1402.

88. Muzard, M.; Aubry, N.; Plantier-Royon, R.; O'Donohue, M.; Remond, C. Evaluation of the transglycosylation activities of a GH $39 \beta$-D-xylosidase for the synthesis of xylose-based glycosides. J. Mol. Catal. B Enzym. 2009, 58, 1-5. [CrossRef]

89. Nacos, M.K.; Katapodis, P.; Pappas, C.; Daferera, D.; Tarantilis, P.A.; Christakopoulos, P.; Polissiou, M. Kenaf xylan-A source of biologically active acidic oligosaccharides. Carbohydr. Polym. 2006, 66, 126-134. [CrossRef]

90. Vazquez, M.J.; Alonso, J.L.; Dominguez, H.; Parajo, J.C. Xylooligosaccharides: Manufacture and applications. Trends Food Sci. Technol. 2000, 11, 387-393. [CrossRef]

91. Samanta, A.C.; Jayapal, N.; Jayaram, C.; Roy, S.; Kolte, A.P.; Senani, S.; Sridhar, M. Xylooligosaccharides as prebiotics from agricultural by-products: Production and applications. Bioact. Carbohydr. Diet. Fibre 2015, 5, 62-71. [CrossRef]

92. Aachary, A.A.; Prapulla, S.G. Xylooligosaccharides (XOS) as an Emerging Prebiotic: Microbial Synthesis, Utilization, Structural Characterization, Bioactive Properties and Applications. Compr. Rev. Food Sci. 2011, 10, 2-16. [CrossRef]

93. Kabel, M.A.; Kortenoeven, L.; Schols, H.A.; Voragen, A.G. In vitro fermentability of differently substituted xylo-oligosaccharides. J. Agric. Food Chem. 2002, 50, 6205-6210. [CrossRef]

94. Immerzeel, P.; Falck, P.; Galbe, M.; Adlercreutz, P.; Nordberg Karlsson, E.; Stålbrand, H. Extraction of water-soluble xylan from wheat bran and utilization of enzymatically produced xylooligosaccharides by Lactobacillus bifidobacterium and Weissella spp., LWT. Food Sci. Technol. 2014, 56, 321-327. [CrossRef]

95. Driss, D.; Zouari-Ellouzi, S.; Chaari, F.; Kallel, F.; Ghazala, I.; Bouaziz, F.; Chaabouni, S.E. Production and in vitro evaluation of xylooligosaccharides generated from corncobs using immobilized Penicillium occitanis xylanase. J. Mol. Catal. B Enzym. 2014, 102, 146-153. [CrossRef]

96. Manju, S.; Chadha, B.S. Biofuels: Alternative Feedstocks and Conversion Processes; Pandey, A., Larroche, C., Ricke, S.C., Dussap, C.G., Gnansounou, E., Eds.; Academic Press: New York, NY, USA, 2011; Volume 9, pp. 203-228. 
97. Verbruggen, M.A.; Beldman, G.; Voragen, A.G.J. The Selective Extraction of Glucuronoarabinoxylans from Sorghum Endosperm Cell Walls using Barium and Potassium Hydroxide Solutions. J. Cereal Sci. 1995, 21, 271-282. [CrossRef]

98. Mathew, S.; Aronsson, A.; Karlsson, E.N.; Adlercreutz, P. Xylo-and arabinoxylooligosaccharides from wheat bran by endoxylanases, utilisation by probiotic bacteria, and structural studies of the enzymes. Appl. Microbiol. Biotechnol. 2018, 102, 3105-3120. [CrossRef] [PubMed]

99. Peng, F.; Peng, P.; Xu, F.; Sun, R.C. Fractional purification and bioconversion of hemicelluloses. Biotechnol. Adv. 2012, 30, 879-903. [CrossRef] [PubMed]

100. Bernfeld, P. Amylases $\alpha$ and $\beta$. In Methods in Enzymology; Kaplan, N., Colowick, S., Eds.; Academic Press: New York, NY, USA, 1955; Volume 1, pp. 149-158.

101. Ratanakhanokchai, K.; Kyu, K.L.; Tanticharoen, M. Purification and Properties of a Xylan-Binding Endoxylanase from Alkaliphilic Bacillus sp. strain K-1. Appl. Environ. Microbiol. 1999, 65, 694-697. [PubMed]

102. Huang, D.; Liu, J.; Qi, Y.; Yang, K.; Xu, Y.; Feng, L. Synergistic hydrolysis of xylan using novel xylanases, $\beta$-xylosidases, and an $\alpha$-L-arabinofuranosidase from Geobacillus thermodenitrificans NG80-2. Appl. Microbiol. Biotechnol. 2017, 101, 6023-6037. [CrossRef]

103. Broekaert, W.F.; Courtin, C.M.; Verbeke, K.; Van de Wiele, T.; Verstraete, W.; Delcour, J.A. Prebiotic and other health-related effects of cereal-derived arabinoxylans, arabinoxylan-oligosaccharides and xylooligosaccharides. Crit. Rev. Food Sci. Nutr. 2011, 51, 178-194. [CrossRef]

104. Yan, Q.J.; Wang, L.; Jiang, Z.Q.; Yang, S.Q.; Zhu, H.F.; Li, L.T. A xylose-tolerant beta-xylosidase from Paecilomyces thermophila: characterization and its coaction with the endogenous xylanase. Bioresour. Technol. 2008, 99, 5402-5410. [CrossRef]

105. Horneck, G.; Walter, N.; Westall, F.; Grenfell, J.L.; Martin, W.F.; Gomez, F.; Leuko, S.; Lee, N.; Onofri, S.; Tsiganis, K.; et al. AstRoMap European Astrobiology Roadmap. Astrobiology 2016, 16, 201-243. [CrossRef]

106. Sinha, R.P.; Häder, D.P. UV-induced DNA damage and repair: A review. Photochem. Photobiol. Sci. 2002, 1, 225-236. [CrossRef] [PubMed]

107. Setlow, P. Spores of Bacillus subtilis: Their resistance to and killing by radiation, heat and chemicals. J. Appl. Microbiol. 2006, 101, 514-525. [CrossRef] [PubMed]

108. Nordberg, H.; Cantor, M.; Dusheyko, S.; Hua, S.; Poliakov, A.; Shabalov, I.; Smirnova, T.; Grigoriev, I.V.; Dubchak, I. The genome portal of the Department of Energy Joint Genome Institute: 2014 updates. Nucleic Acids Res. 2014, 42, D26-D31. [CrossRef] [PubMed]

109. Kanehisa, M.; Goto, S. KEGG: Kyoto Encyclopedia of Genes and Genomes. Nucleic Acids Res. 2000, $28,27-30$. [CrossRef] [PubMed]

110. Casillo, A.; Lanzetta, R.; Parrilli, M.; Corsaro, M.M. Exopolysaccharides from Marine and Marine Extremophilic Bacteria: Structures, Properties, Ecological Roles and Applications. Mar. Drugs 2018, 16, 69. [CrossRef] [PubMed]

111. Di Donato, P.; Buono, A.; Poli, A.; Finore, I.; Abbamondi, G.R.; Nicolaus, B.; Lama, L. Exploring the marine environments for the identification of extremophiles and their enzymes for sustainable and green bioprocesses. Review. Sustainabylity 2019, 11, 149. [CrossRef]

112. Poli, A.; Finore, I.; Romano, I.; Gioiello, A.; Lama, L.; Nicolaus, B. Microbial Diversity in Extreme Marine Habitats and Their Biomolecules. Microorganisms 2017, 5, 25. [CrossRef]

113. Juturu, V.; Wu, J.C. Microbial Exo-xylanase: A mini Review. Appl. Biochem. Biotechnol. 2014, 174, 81-92. [CrossRef]

(C) 2019 by the authors. Licensee MDPI, Basel, Switzerland. This article is an open access article distributed under the terms and conditions of the Creative Commons Attribution (CC BY) license (http://creativecommons.org/licenses/by/4.0/). 